\title{
An Empirical Study of How Household Energy Consumption Is Affected by Co-Owning Different Technological Means to Produce Renewable Energy and the Production Purpose
}

\author{
Lucas Roth ${ }^{1, *}$, Jens Lowitzsch ${ }^{1}$ and Özgür Yildiz ${ }^{2,3}$ (1) \\ 1 Kelso-Professorship for Comparative Law, East European Economic Law and European Legal Policy, \\ Faculty of Business Administration and Economics, European University Viadrina, Grosse Scharrnstr. 59, \\ 15230 Frankfurt (Oder), Germany; lowitzsch@europa-uni.de \\ 2 Department of Environmental Economics and Economic Policy, Technische Universität Berlin, Str. des 17. \\ Juni 135, 10623 Berlin, Germany; oezguer.yildiz@campus.tu-berlin.de \\ 3 Advyce $\mathrm{GmbH}$, Brunnstraße 7, 80331 München, Germany \\ * Correspondence: roth@europa-uni.de; Tel.: +49-(0)335-5534-2560
}

\section{check for} updates

Citation: Roth, L.; Lowitzsch, J.; Yildiz, Ö. An Empirical Study of How Household Energy Consumption Is Affected by Co-Owning Different Technological Means to Produce Renewable Energy and the Production Purpose. Energies 2021, 14 , 3996. https://doi.org/10.3390/ en14133996

Academic Editors: Sergey Zhironkin and Manuela Tvaronavičienè

Received: 6 May 2021

Accepted: 22 June 2021

Published: 2 July 2021

Publisher's Note: MDPI stays neutral with regard to jurisdictional claims in published maps and institutional affiliations.

Copyright: (c) 2021 by the authors. Licensee MDPI, Basel, Switzerland. This article is an open access article distributed under the terms and conditions of the Creative Commons Attribution (CC BY) license (https:// creativecommons.org/licenses/by/ $4.0 /)$.

\begin{abstract}
The transition from fossil fuel-based to renewable energy sources is one of the main economic and social challenges of the early 21st century. Due to the volatile character of wind and solar power production, matching supply and demand is essential for this transition to be successful. In this context, the willingness of private consumers to use energy flexibly has gained growing attention. Research indicates that a viable driver to motivate consumers to be demand flexible is to make them (co-)owners of renewable energy production facilities. However, existing research has only analyzed this question from an aggregated perspective. This article analyses whether behavioral changes triggered by (co-)ownership in renewables differ according to the type of installation; be it solar, wind, or bioenergy. In addition, the prosumption options self-consumption/self-consumption and sale/sale are considered. To do so, we collected 2074 completed questionnaires on energy consumption that entered an econometric model using propensity score matching to control for estimation biases. We find significant differences in the willingness to consume electricity in a flexible manner for (co-)owners of solar installations. However, only the usage of household appliances proves to be statistically significant $(p$-value $=0.04)$. Furthermore, the results show that within the group of (co-)owners of solar installation, the choice between self-consumption and sale of the produced energy has a significant effect on the inclination to become demand flexible ( $p$-value $\leq 0.001$; $p$-value $=0.003$ )
\end{abstract}

Keywords: renewable energy; consumer ownership; demand flexibility; demand side management; propensity score matching; solar energy

\section{Introduction}

Producing energy from renewable sources has gained increasing support in Europe and throughout the world. The authors of [1] predict that the largest share of capacity increase in the years to come will be shouldered by photovoltaic (PV) installations and wind turbines. In their market analysis and forecast from 2018 to 2023, PV and wind power alone will account for approximately 75 percent of growth in the renewable energy (RE) sector. (This article focuses solely on electric energy). The abbreviation RE therefore means exclusively renewable energy in terms of electricity production.

The volatile nature of both technologies poses numerous technical and economic challenges. From an infrastructure perspective, the predominantly centralized electricity grid systems run into difficulties when loads vary in short intervals and with significant values, e.g., rapid declines or increases in power production, for instance, when wind turbines or PV installations cannot produce as forecasted due to unexpected weather 
changes. A constant baseload from fossil energy sources can stabilize the grid system and mitigate critical events triggered by volatile renewable energy sources (vRES) that threaten to impair grid stability [2]. However, this solution conflicts with the declared political aim of an ever-increasing market penetration of renewables in the European Union [3]. Furthermore, under this approach, coping with an increasing amount of vRES in the electricity mix also requires the capability of quick reaction which strongly increases the overall system cost due to a combination of low operation times and high per unit production cost of the most flexible backup generation technologies, for instance, of modern gas turbines [4]. From an economic perspective, cumulated production amounts of vRES cause market-related challenges. If the share of available energy in domestic or international energy markets fluctuates unexpectedly, energy prices follow common market laws. The invert relationship between price and supply results in dramatically depleting, sometimes even negative, electricity prices in cases of unexpected oversupply caused by weather changes, that are often difficult to predict. Regulation to incentivize renewables, such as priority dispatch of renewables into the grid, worsens the resulting economic inefficiency [5]. Given the latest political endorsement for PV and wind energy in major economies, both effects are expected to worsen if not controlled for as the share of vRES is on the rise in the foreseeable future [1].

One possibility to mitigate both effects described above is to apply a broad spectrum of demand side management (DSM). DSM comprises all measures (e.g., flexibilization of demand) undertaken on the consumption side to stabilize the grid system. Strategies for promoting sustainable behavior and flexible demand are manifold.

The involvement of citizens in community energy projects is often mentioned as a particularly promising approach. The underlying rationale is that the direct participation of citizens in energy projects through (co-)ownership deepens the personal involvement with questions of energy consumption and thus promotes sustainable behavior suitable to support the infrastructure system.

Initial findings from research in this context show that there is a link between the role of being a (co-)owner in energy projects and personal energy consumption behavior $[6,7]$. However, these studies share that the characteristic of (co-)ownership is only examined without differentiating according to the underlying technology used to produce RE. Nonetheless, the type of installation deserves special attention as available technologies differ regarding background characteristics, such as the technical complexity of the operation or the spatial proximity between energy production and consumption. For example, solar energy systems are easier to handle during operation than wind power plants and production as a rule takes place closer to consumption in particular with rooftop systems [8]. This paper takes up those technological differences. The research goal is to deepen the growing body of literature on demand side management and analyze the question whether there is a relationship between (co-)ownership of renewable energy production facilities, the applied technology, and energy consumption behavior. To do so, an empirical analysis with propensity score matching methodology is applied.

\section{Literature Review}

The sustainability and security of economic development around the globe are based on the smooth and uninterrupted supply and demand mechanisms of energy sources [9]. The current stage of the international energy sector transformation is characterized by a growth in demand for energy supply and intensified use of renewable energy sources (RES) resulting in a higher fluctuation of energy supply and technical challenges stemming thereof [10]. To deal with the challenge of providing stability and flexibility to energy systems that include a high proportion of vRES, several strategies involving utilities, grid operators, regulatory bodies, policy-makers, and consumers are pursued. These strategies can be distinguished into three main categories: energy efficiency (EE), on-site back-up systems, and flexibilization. In this context, flexibilization, i.e., measures that encourage consumers to load shifting, is considered as particularly attractive as it mainly relies on 
capacities that already exist and therefore is theoretically easy to implement [11]. While the effectiveness of flexibilization at the demand side in general is debated, given an increasing share of vRES, the bulk of research and practical experience supports its advantages and suitability to contribute to support infrastructure stability [12-15]. Approaches to systematically characterize DSM measures identify strategies which include among others technical strategies such as remote control or in-home displays for load and consumption transparency [16,17], dynamic pricing strategies to promote demand response [18], information campaigns for energy consumers, e.g., the diffusion of good practices, and regulatory measures, like utility obligations, product standards, and product labeling [15] with all of these strategies being able to operate on the household and the industrial sector level.

When focusing on DSM at the household level, various factors can be used as triggers to bring private consumers to apply demand side measures. A widely discussed approach in the scientific discourse and energy industry practice is to equip households with smart appliances and face them with variable electricity prices. These variable pricing schemes can be time-based (see, e.g., in [19-21]) or schemed to optimize distribution grid services [22,23]. A second approach focuses on the provision of information through traditional communication channels such as information brochures and billing letters or smart meter devices in order to promote flexible behavior (see, e.g., in [24,25]). The provision of information has in general been proven to be an effective measure to induce changes in energy consumption behavior and people's opinion towards renewable energy [26]. Another factor that can be used to bring private consumers to apply demand side measures is the appeal to norms. In this context, aspects such as environmental concern are tested to enable load-shifting (and other energy conservation behaviors) among end users with mixed results on the actual efficacy of such measures (see, e.g., in [27-29]). In line with this rather psychological approach, Frederiks et al. [30] explained energy consumption behavior with biased perception, consumer heuristics, and other irrational inclinations. Furthermore, other cognitive and contextual factors can have an influence on an individual's behavior in the context of energy-related topics and therefore also in the context of electricity consumption and demand flexibility. These factors include the awareness of the problem, e.g., an individual's understanding and knowledge on energy-related questions such as grid stability and supply security; nuances of media coverage, e.g., the variety of information sources and its evaluation; and finally, trust in the energy system's stability [31]. Accordingly, much more attention should be given to these aspects when analyzing the behavioral aspects of energy consumption [32]. In this context, business models involving citizens as (co-)owners of RE and thus as prosumers are of particular interest as they combine several possible influences on an individual's energy consumption. These business models, often referred to in the literature as community energy (see, e.g., in [33]) or citizen energy (see, e.g., in [34]), either involve citizens in project planning and financing with self-consumption having a subordinate role, or they explicitly foster prosumership and address several of the above-mentioned triggers to promote demand flexibility [35]. Therefore, the behavior of energy consumers involved in citizen energy projects has been the focus of various scientific papers. Among others, Anda and Temmen [36] find that community-based social marketing has shown to be very effective at inducing behavioral change towards a more efficient and flexible energy use. Another study from Hoppe et al. [37] shows that in addition to psychological and socio-demographic variables, the characteristic framework of an energy cooperative, as a particular business model for citizen energy, can contribute to more engagement in energy-saving actions and reported energy conservation. Another approach by Goulden et al. [38] revealed that citizen participation in energy production and energy consumption holds great potential for various kinds of DSM measures in a non-commercial context. Further, the authors of [7] showed that different prosumption options for produced electricity impact demand flexible behavior as well, depending on whether produced electricity can be used for self-consumption, sale, or both.

However, all these papers have a restriction in common, i.e., the participants of citizen energy projects are analyzed as a homogenous group in comparison to non-participants 
without any further distinction of the type of RE conversion technology they are invested in, be it PV, wind, or bioenergy. Kubli et al. [6] discuss the technological background to a limited extent when they showed that people who own PV installations or electric vehicles are more likely to adapt DSM, indicating a relationship between energy technologies and consumption behavior. This study, however, focuses on three different application areas of RE technologies, being photovoltaic heat pumps and electric vehicles, i.e., electricity production, heating, and transportation. Extending and deepening this analysis with regard to other types of RE is important, as the preceding studies show that the application of green technologies is expected to allow for and trigger different behavior. Moreover, conversion technologies have inherently different characteristics that hold potential for various, behavioral implications. For instance, PV systems when compared to wind farms (in particular, offshore), are generally located closer to the prosumer, are smaller in terms of installed capacity requiring smaller investments per unit and offer individual control. The authors derive the leading research hypotheses on this basis.

When looking at RE conversion technologies, biomass, hydropower, geothermal, tidal/wave, solar, and wind energy are identified as technologies with the highest potential to substitute fossil fuels [39]. Among those technologies, biomass, wind, and solar energy have the largest potential in terms of installed capacity and are expected to be the most prevalent in the future [40], which is why the following analysis focuses on these technologies. Drawing on results of the data analysis the authors combine the two aspects of conversion technology and prosumption options to refine the picture further. Availability of data permitting, each conversion technology is analyzed in association with the three options to use electricity produced, i.e., (i) self-consumption, (ii) sale to third parties, and (iii) the choice between self-consumption and sale.

Regarding the conversion technology, in line with the work in [6], it is assumed that people who (co)-own solar power plants are inclined to be more willing to exercise demand flexible behavior than the other groups. Further, in line with Goulden et al. [38], a general involvement in RE in other technologies is expected to trigger a more flexible consumption as compared to no involvement.

For further analyzation, the following abbreviations for group affiliation were used throughout the manuscript:

- Non-owners

- Solar-owners

- Wind-owners

- Biogas-owners

People who are not involved with RE;

People who (co-)own a solar energy power plant;

People who (co-)own a wind turbine;

People who (co-)own a biogas power plant.

At the meta-level, the authors formulate two main hypotheses (A and $\mathrm{B}$ ) regarding the used conversion technology and prosumption options:

Hypothesis A (HA). (Co-)ownership in renewable energy production facilities positively impacts a consumers' willingness to use electricity in a flexible manner. Solar installations hold the largest potential to trigger flexibility in this regard.

This breaks down into six sub-hypotheses:

Hypothesis 1 (H1). Solar-owners are more willing to be demand flexible than Non-Owners.

Hypothesis 2 (H2). Wind-owners are more willing to be demand flexible than Non-Owners.

Hypothesis 3 (H3). Biogas-owners are more willing to be demand flexible than Non-Owners.

Hypothesis $4 \mathbf{( H 4 ) . ~ S o l a r - o w n e r s ~ a r e ~ m o r e ~ w i l l i n g ~ t o ~ b e ~ d e m a n d ~ f l e x i b l e ~ t h a n ~ W i n d ~ o w n e r s . ~}$

Hypothesis 5 (H5). Solar-owners are more willing to be demand flexible than Biogas owners. 
Hypothesis 6 (H6). Wind-owners are more willing to be demand flexible than Biogas owners.

Hypothesis B (HB). The consecutive hypotheses regarding the technology in association with different options to use the produced energy depend on the results of $\mathrm{H1}-\mathrm{H} 6$ as well as the availability of data. Therefore, the respective hypotheses system will be built up after analyzing $\mathrm{H1}-\mathrm{H} 6$.

\section{Methodology}

The following chapters give a brief overview of the sampling process, specifications on measurement, and statistical procedure.

\subsection{Deliberations on Data Collection}

The study was conducted in cooperation with the website www.immobilienscout24.de (accessed on 14 April 2020). The sample was obtained via an online survey using the data base of this website. ImmobilienScout24 is the biggest online real estate platform in Germany. The user base of 14.8 million monthly visitors [41] provides perfect conditions to obtain a representative high-quality sample containing participants holding demographics close to those of the German population. At the same time, it was important to reach a sufficient number of people of interest to this analysis, i.e., (co-)owners of RE production facilities, to enable the researchers to apply the underlying econometric approach which, in this instance, requires a large sample size (cf. Section 3.4). As a real estate platform, the ImmobilienScout24 data base is likely to hold a large share of users which own real estate. The probability of homeowners being involved with energy related questions (e.g., production, self-sufficiency, and energy efficiency) is higher than with typical consumer panels holding less people who live in own property [42].

The participants were invited via e-mail to take part in the study. The invitation text specifically mentioned purposes and involved institutions in the analyzation of the data. In total, the sample consisted randomly chosen users of 135,000 users who have an account with ImmobilienScout24. 4315 potential participants had to be excluded because of personal e-mail settings or technical restriction (Users of the website can restrict their e-mail settings as to not receive any e-mails from ImmobilienScout24. In this case the e-mail addresses had to be excluded. Technical problems can be, for instance, a full e-mail inbox, not existing or deactivated domain). To motivate the participants to complete the whole questionnaire, 5 Amazon vouchers were raffled. Doing so increases the response rate and statistical power in terms of representativity [43,44]. Ultimately 130,685 invitation e-mails were sent which resulted in 2074 completed questionnaires which entered the analysis. The response rate is in line with ordinary expectation for online surveys where people do not expect an e-mail invitation for a study [45-47]. Answers from participants who did not finish the questionnaire might yield bad data quality [48]. Therefore, only completed questionnaires were included in the analysis.

\subsection{Deliberations on Measurement}

To analyze the hypothesis, in a first step, the groups of interest must be distinguished. To do so, the questionnaire included questions regarding a participant's involvement in RE production (the Questionnaire flow, i.e., a summary of all the questions the participants had to go through is depicted in Appendix A. The full version of the questionnaire is depicted in Appendix B. Please note that the original questionnaire was in German. Under each questionnaire screenshot an English translation can be found). Further, to determine a personal level of demand flexibility the participants had to rate their willingness to consume energy in a flexible way for three different electricity consumption settings on a Likert scale possible answers being graded from 1 for "I strongly disagree" to 5 "I strongly agree". The electricity consumption settings were chosen after a literature analysis that the questionnaire was based on. Possibilities for demand flexibility are discussed in several domains. For instance, Firth et al. [49], Naus et al. [50], and Moser [51] highlight the importance of household appliances and mobile electrical devices. Further, Kubli et al. [6] 
and Pallonetto et al. [52] underline the inclusion of electrical means of transportation for load shifting approaches. Consequently, the following individual electricity consumption settings were selected:

I am willing to ...

... use household appliances (e.g., washing machine, dishwasher, etc.) mainly when the share of electricity from renewable sources in the grid is very high.

... recharge electrical devices (e.g., laptop) mainly when the share of electricity from renewable sources in the grid is very high.

... recharge electrical means of transportation (e.g., electric car/scooter/bike) mainly when the share of electricity from renewable sources in the grid is very high.

The rated answers to those dimensions are the basis to calculate a measure for demand flexibility in different domains and compare it among the defined research groups. A complete data summary and codebook of all used variables to test the hypotheses can be found in Tables A1 and A2 in Appendix C.

\subsection{Deliberations on the Sample}

Using an explorative approach, the data quality of the sample was evaluated. A series of pre-tests revealed that it was not possible to seriously answer all questions when spending less than 4 min on the questionnaire; the questionnaire software automatically discarded those cases, resulting in an initial data set of 2143 completed questionnaires. The evaluation further revealed that some participants gave inconsistent answers by clicking back and forth in the questionnaire. Therefore, in a second step, cases were manually excluded if participants gave contradictory answers (for instance, a participant selected "yes" with an involvement in RE, answered all consecutive questions on the RE installation, but then went back to the first question and altered the answer for the involvement with RE to "no".). To avoid any contextual and statistical ambiguities, participants who (co)own more than one installation in different technological domains or select the "else" (for instance, participants indicated that they participate renewable energy production projects. When they are asked in which way they are involved they gave answers like and gave an answer in the free text field next to the) option and thereby indicating a technology, which was not relevant for the analysis, were excluded from the analysis as well. In doing so, ultimately, a sample of 2074 was used to test the hypotheses. The Table A3 in Appendix D depicts the data cleaning process with the respective number of deleted cases in each step.

\subsection{Deliberations on the Model Specification}

A statistical analysis with the aim to examine differences in groups on a specific target variable is prone to suffer from estimation biases. Biases arise with general differences in characteristics of the research groups. In this instance, specific biases could result from the non-random sampling procedure (online survey). Therefore, the reference groups could have fundamentally different predispositions which influence the dependent variable (here demand flexibility) rather than being a (co-)owner. To control for estimation biases, a matching procedure is applied. Matching can be used in a variety of scenarios when comparing groups on a dichotomous variable (here being a (co-)owner of a certain technology with a subsequent usage possibility of produced energy). The aim is to artificially randomize the sample by homogenizing the comparison groups; in other words, to make them comparable on demographic covariates. The matching itself is based on different initial characteristics of the participants. To applied matching technic must ensure the highest similarity possible of those characteristics in both groups.

In those instances, propensity score matching (PSM) has proven to be a reliable approach for observational studies in general (see, e.g., in $[53,54]$ ) and web-surveys in specific (see, e.g., in [55-57]). PSM was developed by Rosenbaum and Rubin [58]. It channels all relevant characteristics into an individual score for each participant reflecting 
the probability of belonging to a certain group. Subsequently, the matching procedure is run based on the individual scores.

To execute the described PSM, in a first step, it is necessary to identify crucial characteristics of the participants that influence their probability on being involved with RE. A statistical approach to do so is a logistic regression that estimates the influence of categorical or continues independent variables on a binary outcome variable, in this instance being a (co-)owner or not. The regression was run using all available demographics (cf. data summary in Appendix C). A summary of the regression results is depicted in Table A4 in Appendix D. The procedure revealed that gender, age, net income, and population of the city/village have a significant impact on whether people are (co-)owners of renewable energy production facilities. Therefore, they enter the model as independent variables to calculate the propensity score.

To ensure an evenly balanced influence of all predictors when calculating the propensity scores, the varying scale levels were unified by applying a standardized z-score. Equation (1) describes this procedure.

$$
z=\frac{x-\mu}{\sigma}
$$

$z$ corresponds to a demographic variable after the standardisation. $x$ stands for the original scale value from a single participant and $\mu$ is the sample mean of variable $x$. $\sigma$ corresponds to the standard deviation of the sample for variable $x$. In summary, one subtracts the sample mean $\mu$ from the original scale value $x$ and divides this result by the standard deviation $\sigma$ of the sample [59]. This procedure is run for all demographic variables for each participant.

The propensity score was calculated using pscore syntax in Stata 16. Equation (2) depicts a generic model that was run for each of the hypotheses. It describes the procedure on how the propensity score is estimated using a probabilistic model.

$$
\text { Treatment }=\left(\frac{P_{i}}{1-P_{i}}\right)=\beta_{0}+\beta_{1} \text { Gender }+\beta_{2} \text { Age }+\beta_{3} \text { NetIncome }+\beta_{4} \text { Location }+\varepsilon_{i}
$$

$\left(\frac{P_{i}}{1-P_{i}}\right)$ corresponds to the outcome variable for observation $i . \beta_{1}$ to $\beta_{4}$ stand for the slope coefficients for gender, age, net income, and location (meaning the population in the respective city/village). $\varepsilon_{i}$ is an error term loaded with other variables that might influence the propensity score.

After the scores are calculated, different matching techniques are available to mathematically form treatment and control group. In this paper, the authors decided to apply the commonly used nearest neighbor algorithm. When calculating the mean difference of the outcome variable, i.e., the Average Treatment Effect on the Treated (ATT), a sufficient common support must be ensured to evaluate the influence that group affiliation has on demand flexibility.

As often the case with observational studies, the data at hand are skewed towards the positive end of the outcome variable. This circumstance leads a violation of the normality assumption with parametric test procedures, such as a simple mean comparison. To account for the lack of normality of the data a nonparametric bootstrap is applied. When using the bootstrap, no specific distribution is assumed. Rather the distribution of the outcome variable is estimated through a resampling procedure. To do so, one needs to draw new samples from the original sample (resampling). The resulting empirical distribution function can be used to obtain confidence intervals and related hypotheses test without the requirements of normality, equality of variances or specific distribution shapes [60]. Equations (3) and (4) show an exemplary resampling procedure. The process is described as

$$
E \rightarrow x=\left(x_{1}, x_{2}, \ldots, x_{n}\right) \rightarrow T(x)
$$


with the unknown distribution $E$, the random sample $x$ as well as the outcome variable $T(x)$ where one draws $n$ times with replacement from $\left(x_{1}, x_{2} \ldots, x_{n}\right)$ to generate the bootstrap sample

$$
\hat{E} \rightarrow x^{*}=\left(\mathrm{x}_{1}^{*}, \mathrm{x}_{2}^{*}, \ldots, \mathrm{x}_{n}^{*}\right) \rightarrow T\left(x^{*}\right)
$$

with the empirical distribution $\hat{E}$ of the bootstrap sample $x^{*}$ the outcome variable $T\left(x^{*}\right)$ based on the empirical distribution. It is vital to set a sufficient number of sampling repetitions which is usually reached when a further increase does not change $T\left(x^{*}\right)$. To guarantee a maximum level of security, the above-mentioned procedure is run 5000 times, which is in line with recommendations from scientific literature $[61,62]$.

\section{Results and Hypothesis Testing}

The results section is structured according to hypotheses that compare (i) demand flexibility along the form of participation and subsequently (ii) demand flexibility within the group of consumers that (co-)own PV installations along the usage possibilities of the produced energy. All hypotheses were tested using the matching technique described in Section 3.4. The defined specifications yield consistent diagnostics showing significant PSM estimates throughout all test scenarios. Additionally, for all specifications that yield results the assumption of common support is maintained. The latter is a prerequisite for the second step of the test procedure, i.e., the calculation of the ATT, for all defined specifications. A hypothesis is preliminary confirmed if the error probability is below 5 percent $(\alpha=0.95)$.

\subsection{Comparison According to Type of Renewable Energy Source}

The first six hypotheses look at differences in demand flexible behavior based on the type of energy source the consumer (co-)owns. The considered types of RES are solar power plants, wind turbines, and biogas plants. Thereby, the different RE conversion technologies are compared among each other as well as with consumer who are not involved with Renewables at all.

\section{H1. Solar owners are more willing to be demand flexible than non-owners.}

All analyzed dimensions of demand flexibility are depicted in Table 1. Each dimension holds values for the group size of treated and controls in the column observations (OBS). The ATT corresponds to the mean difference between the groups. Additionally, the tand $p$-value, respectively, indicate whether the observed treatment effect is significant. To partially confirm a hypothesis the $p$-value must be smaller than 0.05 , i.e., below the previously defined error probability of 5 percent.

Table 1. Demand flexibility comparisons of solar owners (treated) versus non-owners (controls) (source: authors' own calculations). Note: ${ }^{* \prime}$ denote statistical significance levels ( ${ }^{* * *} 1$ percent; ${ }^{* *} 5$ percent).

\begin{tabular}{|c|c|c|c|c|c|c|}
\hline Dimension & Group & OBS & Mean & ATT & $t$-Value & $p$-Value \\
\hline Usage of household appliances & $\begin{array}{l}\text { Treated } \\
\text { Controls }\end{array}$ & $\begin{array}{l}218 \\
670\end{array}$ & $\begin{array}{c}3.612^{1} \\
3.382\end{array}$ & $0.231 * *$ & 1.722 & 0.043 \\
\hline Charging electrical appliances & $\begin{array}{l}\text { Treated } \\
\text { Controls }\end{array}$ & $\begin{array}{l}218 \\
671\end{array}$ & $\begin{array}{l}3.114 \\
3.054\end{array}$ & 0.060 & 0.402 & 0.344 \\
\hline $\begin{array}{l}\text { Charging electrical means } \\
\text { of transportation }\end{array}$ & $\begin{array}{l}\text { Treated } \\
\text { Controls }\end{array}$ & $\begin{array}{l}218 \\
572\end{array}$ & $\begin{array}{l}3.489 \\
3.405\end{array}$ & 0.084 & 0.548 & 0.292 \\
\hline
\end{tabular}

${ }^{1}$ Differences between depicted means and ATT can occur due to applied rounding rules; statistics software considers six decimal places.

For $\mathrm{H} 1$ the treatment group consists of consumers who are (co-)owners of a solar installation (solar owners) and the controls are consumers who are not involved with RE (non-owners). Throughout all dimensions, the results show that people who (co-)own solar installations tend to be more demand flexible than people who are not involved with RE. However, only the first dimension, the usage of household appliances proves to be statistically significant. In average, solar owners are $0.231^{* *}$ scale points more willing to be 
demand flexible when compared to non-owners. The mean differences for charging of other electrical appliances as well as electrical means of transportation amount to 0.060 and 0.084 , respectively. Therefore, they are rather small and have to be discarded as insignificant. Therefore, $\mathrm{H} 1$ is partially confirmed. Based on the underlying data, it can be concluded that people who are (co-)owners of a solar installation are in average more willing to be demand flexible than people who have no junction to the production of energy from renewable sources but only when looking at the usage of household appliances.

\section{H2. Wind owners are more willing to be demand flexible than Non-owners.}

$\mathrm{H} 2$ looks at the differences between people who are involved with RE production from wind turbines (wind owners) as the treated group and non-owners as controls. Following the calculated ATT (Table 2), the wind owners are more willing to be demand flexible; at least from a descriptive perspective. The mean difference for the usage of household appliances, in this instance, amounts to 0.210 scale points. The biggest ATT can be observed with the charging of other electrical appliances and amounts to 0.362 . For the charging of electrical means of transportation, the average mean difference equals 0.140 . However, throughout all dimensions, the $p$-value is bigger than 0.05 . Therefore, all results are statistically not significant and must be discarded. In the context of this study, there is no difference in the willingness to be demand flexible between people who (co-)own wind turbines and people that are not involved with RE.

Table 2. Demand flexibility comparisons of Wind-owners (treated) versus Non-Owners (controls) (source: authors' own calculations).

\begin{tabular}{|c|c|c|c|c|c|c|}
\hline Dimension & Group & OBS & Mean & ATT & $t$-Value & $p$-Value \\
\hline \multirow{2}{*}{ Usage of household appliances } & Treated & 20 & 3.850 & \multirow[b]{2}{*}{0.210} & \multirow{2}{*}{0.511} & \multirow{2}{*}{0.305} \\
\hline & Controls & 92 & 3.640 & & & \\
\hline \multirow{2}{*}{ Charging electrical appliances } & Treated & 20 & 3.350 & \multirow{2}{*}{0.362} & \multirow{2}{*}{0.781} & \multirow{2}{*}{0.218} \\
\hline & Controls & 92 & 2.988 & & & \\
\hline \multirow{2}{*}{$\begin{array}{l}\text { Charging electrical means } \\
\text { of transportation }\end{array}$} & Treated & 20 & 3.400 & \multirow{2}{*}{0.140} & \multirow{2}{*}{0.335} & \multirow{2}{*}{0.369} \\
\hline & Controls & 82 & 3.260 & & & \\
\hline
\end{tabular}

H3. Biogas-owners are more willing to be demand flexible than Non-owners.

The third hypothesis compares the willingness to be demand flexible from people who are (co-)owners of a biogas plant (Biogas-owners) against Non-owners. The former represents the treatment, whereas the latter serve again as controls. The analysis of $\mathrm{H3}$ reveals that from a descriptive perspective Biogas-owners tend to be less demand flexible than Non-owners (Table 3). The ATT for the usage of household appliances indicates that Biogas-owners are on average 0.408 scale points less demand flexible than Non-owners within the scope of the usage of household appliances. The mean difference for the charging of other electrical appliances is with -0.092 less severe. The largest ATT can be observed with the charging of electrical means of transportation and amounts to -0.667 . Regardless of the negative tendencies, all results yield insufficient $t$-values and therefore must be discarded as insignificant. In this instance, it is important to note that the number of observations in both groups is rather low. This circumstance limits the explanatory power of the whole H3. Nevertheless, within the scope if this analysis, the H3 must be utterly rejected. There is no difference in the willingness to be demand flexible for people who (co-)own a biogas plant and those who are not involved with RE. 
Table 3. Demand flexibility comparisons of Biogas-owners (treated) versus Non-Owners (controls) (source: authors' own calculations).

\begin{tabular}{|c|c|c|c|c|c|c|}
\hline Dimension & Group & OBS & Mean & ATT & $t$-Value & $p$-Value \\
\hline Usage of household appliances & $\begin{array}{l}\text { Treated } \\
\text { Controls }\end{array}$ & $\begin{array}{c}5 \\
17\end{array}$ & $\begin{array}{l}3.400 \\
3.808\end{array}$ & -0.408 & -0.379 & 0.354 \\
\hline Charging electrical appliances & $\begin{array}{l}\text { Treated } \\
\text { Controls }\end{array}$ & $\begin{array}{c}5 \\
17\end{array}$ & $\begin{array}{l}3.000 \\
3.092\end{array}$ & -0.092 & -0.084 & 0.467 \\
\hline $\begin{array}{l}\text { Charging electrical means } \\
\text { of transportation }\end{array}$ & $\begin{array}{c}\text { Treated } \\
\text { Controls }\end{array}$ & $\begin{array}{c}5 \\
15\end{array}$ & $\begin{array}{l}3.200 \\
3.867\end{array}$ & -0.667 & -0.641 & 0.265 \\
\hline
\end{tabular}

H4. Solar-owners are more willing to be demand flexible than Wind-owners.

$\mathrm{H} 4$ considers differences in expressed willingness to behave in a demand flexible manner between Solar-owners (treated) and Wind-owners (controls). The ATT indicates a negative treatment effect in all analyzed dimensions (Table 4). For the usage of household appliances, the average mean difference between Solar-owners and Wind owners amounts to -0.864 scale points in favor of the latter. The ATT for the charging of electrical appliances is -0.600 . The average mean difference for electrical means of transportation is with -0.266 the smallest. Even though, one observes a tendency that Wind-owners are more willing to be demand flexible than Solar-owners, all dimensions yield insufficient $\mathrm{t}$ - and corresponding $p$-values. The observable tendencies are all statistically insignificant.

Table 4. Demand flexibility comparisons of Solar-owners (treated) versus Wind-owners (controls) (source: authors' own calculations).

\begin{tabular}{|c|c|c|c|c|c|c|}
\hline Dimension & Group & OBS & Mean & ATT & $t$-Value & $p$-Value \\
\hline Usage of household appliances & $\begin{array}{l}\text { Treated } \\
\text { Controls }\end{array}$ & $\begin{array}{c}218 \\
18\end{array}$ & $\begin{array}{l}3.077 \\
3.941\end{array}$ & -0.864 & -1.129 & 0.130 \\
\hline Charging electrical appliances & $\begin{array}{l}\text { Treated } \\
\text { Controls }\end{array}$ & $\begin{array}{c}218 \\
18\end{array}$ & $\begin{array}{l}3.096 \\
3.696\end{array}$ & -0.600 & -0.765 & 0.223 \\
\hline $\begin{array}{l}\text { Charging electrical means } \\
\text { of transportation }\end{array}$ & $\begin{array}{l}\text { Treated } \\
\text { Controls }\end{array}$ & $\begin{array}{c}218 \\
14\end{array}$ & $\begin{array}{l}3.149 \\
3.415\end{array}$ & -0.266 & -0.351 & 0.363 \\
\hline
\end{tabular}

Note that the group sizes are unequal to a large extent and the number of observations for people who (co-)own wind turbines is rather small. Both circumstances have a destabilizing effect on the applied testing procedure and need to be evaluated when discussing the results. In the context of this study, there is no difference in willingness to apply demand flexible behavior between people who (co-)own solar installations and wind turbines. $\mathrm{H} 4$ must be utterly rejected.

H5. Solar-owners are more willing to be demand flexible than Biogas-owners.

The $\mathrm{H} 5$ tries to analyze differences in consumption behavior between Solar-owners (treated) and Biogas-owners (controls). However, the analyzation of this particular hypothesis proves to be difficult. In this instance, the treated group contains 218 people who (co-)own solar installations (Table 5). On the other hand, the whole sample solely contains six observations which are (co-)owners of a biogas plant. In the course of the matching procedure, only one observation meets the requirement of common support and enters the analysis. Even though the bootstrap allows to calculate the statistics of interest for the first two dimensions, the interpretation of the results does not make sense due to the insufficient number of cases. In conclusion, differences in consumption behavior between (co-)owners of Solar-installations and biogas plants cannot be analyzed with the data at hand. 
Table 5. Demand flexibility comparisons of Solar-owners (treated) versus Biogas-owners (controls) (source: authors' own calculations). Note: ${ }^{* \prime}$ denote statistical significance levels ( ${ }^{* *} 1$ percent; ${ }^{* *} 5$ percent).

\begin{tabular}{|c|c|c|c|c|c|c|}
\hline Dimension & Group & OBS & Mean & ATT & $t$-Value & $p$-Value \\
\hline Usage of household appliances & $\begin{array}{l}\text { Treated } \\
\text { Controls }\end{array}$ & $\begin{array}{c}218 \\
1\end{array}$ & $\begin{array}{l}3.000 \\
5.000\end{array}$ & $-2.000 * * *$ & -5.806 & $<0.001^{1}$ \\
\hline Charging electrical appliances & $\begin{array}{l}\text { Treated } \\
\text { Controls }\end{array}$ & $\begin{array}{c}218 \\
1\end{array}$ & $\begin{array}{l}4.000 \\
3.000\end{array}$ & $-1.000^{* *}$ & 2.201 & 0.014 \\
\hline $\begin{array}{l}\text { Charging electrical means } \\
\text { of transportation }{ }^{2}\end{array}$ & $\begin{array}{l}\text { Treated } \\
\text { Controls }\end{array}$ & $\begin{array}{c}218 \\
1\end{array}$ & $\begin{array}{c}- \\
3.000\end{array}$ & - & - & - \\
\hline
\end{tabular}

${ }^{1}$ Please note: the authors report $<0.001$ if the calculated $t$-value is smaller than $0.001 .{ }^{2}$ The third dimension does not yield a result because the only matched treated observation does not hold a value, i.e., has selected “I don't know" for this question.

\section{H6. Wind-owners are more willing to be demand flexible than Biogas-owners.}

In $\mathrm{H} 6$, the authors want to compare the willingness to be demand flexible of Windowners (treated) and Biogas-owners (controls). Both groups contain solely 21 and six observations each in the same order (Table 6). The 20 observations viable for matching as treated cannot be matched with any of the six observations who (co-)own biogas plants without violating the diagnostic restrictions. Therefore, similar to the previous hypothesis, the data do not allow analysis of H6. In the context of this study, one cannot analyze whether or not the willingness to apply demand flexibility measures differs between (co-)owners of a wind turbine or a biogas plant.

Table 6. Demand flexibility comparisons of Wind-owners (treated) versus Biogas-owners (controls) (source: authors' own calculations).

\begin{tabular}{|c|c|c|c|c|c|c|}
\hline Dimension & Group & OBS & Mean & ATT & $t$-Value & $p$-Value \\
\hline \multirow{2}{*}{ Usage of household appliances } & Treated & 20 & - & \multirow[t]{2}{*}{ - } & \multirow[t]{2}{*}{-} & \multirow[t]{2}{*}{ - } \\
\hline & Controls & - & - & & & \\
\hline \multirow{2}{*}{ Charging electrical appliances } & Treated & 20 & - & \multirow{2}{*}{-} & \multirow{2}{*}{ - } & \multirow[b]{2}{*}{ - } \\
\hline & Controls & - & - & & & \\
\hline \multirow{2}{*}{$\begin{array}{l}\text { Charging electrical means } \\
\text { of transportation }\end{array}$} & Treated & 20 & - & \multirow{2}{*}{-} & \multirow{2}{*}{ - } & \multirow{2}{*}{ - } \\
\hline & Controls & - & - & & & \\
\hline
\end{tabular}

Summary H1-H6

$\mathrm{H} 1$ to $\mathrm{H} 6$ analyze the differences in reported willingness for demand flexible behavior according to the type of RES a consumer (co-)owns. Thereby, comparisons among (co-)owners of solar installations, wind turbines, biogas plants, and people who are not involved with RE are undertaken. Significant differences in the willingness to consume electricity in a flexible manner were solely found when comparing (co-)owners of solar installations with people who do not (co-)own RE production facilities. However, the comparison within different forms of RES in $\mathrm{H} 5$ and $\mathrm{H} 6$ do not yield viable results due to an insufficient number of cases in each group. The statistical power of the comparisons in H3 (Biogas-owners versus Non-owners) and H4 (Solar-owners versus Wind-owners is also weak due to an unequal distribution of cases as well as a limited number of observations for the Wind-owners.

Regardless of the limitations above, the data allow us to conclude that statistical differences with regard to the willingness to be demand flexible occur when comparing people who are (co-)owners of solar installations with people who have no touchpoints with RE production. That is, it seems that to trigger demand flexible behavior, solar installations are a viable option. 


\subsection{Comparison According to the Usage Possibilities within (Co-)Owners of Solar Power Plants}

The following chapter links this finding of a previous work in [7] where the authors presented empirical evidence that (co-)ownership in RE installations does solely trigger a change in a consumer's behavior if the (co-)owners have the possibility to consume as well as sell energy to the grid at the same time. Given the previously presented results-solar installations being the only RES that goes hand in hand with a significant difference in the willingness to be demand flexible-it is logical to combine both metrics, i.e., analyze differences in the willingness to be demand flexible among, people who are (co-)owners of solar installations and solely consume, consume as well sell at the same time, solely sell and people who are not involved in energy production from renewable sources at all. As already stated, at this point, due to the lack of data a subdivision of other analyzed technologies, i.e., wind and biogas, into the different usage possibilities is statistically not senseful.

For further analyzation, the following abbreviations for group affiliation in terms of energy usage options were used throughout the manuscript:

- Non-owners

People who are not involved with RE;

- Solar-consumers People who (co-)own solar installations and solely

- Solar-consellers consume produced RE;

- Solar-sellers People who (co-)own solar installations and consume as well as sell RE at the same time; People who (co-)own solar installations and solely sell produced RE.

Returning to the 2 meta-level hypotheses from Section 2, the following second main hypothesis is analyzed.

Hypothesis B (HB). Only the prosumption option of consuming and selling produced electricity from solar installations at the same time positively impacts a consumers' willingness to use electricity in a flexible manner.

This breaks down into six sub-hypotheses:

Hypothesis 7 (H7). Solar-consumers are more willing than Non-owners.

Hypothesis 8 (H8). Solar-consellers are more willing than Non-owners.

Hypothesis 9 (H9). Solar-sellers are more willing than Non-owners.

Hypothesis 10 (H10). Solar-consellers are more willing than Solar-consumers.

Hypothesis 11 (H11). Solar-consellers are more willing that Solar-sellers.

Hypothesis 12 (H12). Solar-sellers are more willing than Solar-consumers.

H7. Solar-consumers are more willing to be demand flexible than Non-owners.

H7 compares differences in intended consumption behavior between people who solely consume energy produced by their solar installations (Solar-consumers) and people who are not involved with RE (Non-owners). The treatment is assigned to the Solarconsumers and the Non-owners serve as controls. The ATT point jointly towards a negative direction for all analyzed dimensions (Table 7). The mean difference for the usage of household appliances is 0.034 scale points smaller in the group of the Solar-consumers as opposed to the Non-owners. The biggest difference can be observed with the charging of other electrical appliances and amounts to -0.120 scale points. Last, the smallest difference is -0.011 scale points and can be found with the charging of electrical means of transportation. Even though, one observes a tendency that the Solar-consumers are less 
flexible in their demand than Non-owners throughout all dimensions, all results have to be discarded as insignificant. H7 must be rejected. In this analysis, there is no difference in the expressed willingness to be demand flexible between people who (co-)own solar installations and people who are not involved with RE production.

Table 7. Demand flexibility comparisons of Solar-consumers (treated) versus Non-owners (controls) (source: authors' own calculations).

\begin{tabular}{|c|c|c|c|c|c|c|}
\hline Dimension & Group & OBS & Mean & ATT & $t$-Value & $p$-Value \\
\hline Usage of household appliances & $\begin{array}{l}\text { Treated } \\
\text { Controls }\end{array}$ & $\begin{array}{l}128 \\
509\end{array}$ & $\begin{array}{l}3.347 \\
3.381\end{array}$ & -0.034 & -0.191 & 0.424 \\
\hline Charging electrical appliances & $\begin{array}{l}\text { Treated } \\
\text { Controls }\end{array}$ & $\begin{array}{l}128 \\
510\end{array}$ & $\begin{array}{l}2.976 \\
3.096\end{array}$ & -0.120 & -0.674 & 0.250 \\
\hline $\begin{array}{l}\text { Charging electrical means } \\
\text { of transportation }\end{array}$ & $\begin{array}{l}\text { Treated } \\
\text { Controls }\end{array}$ & $\begin{array}{l}128 \\
442\end{array}$ & $\begin{array}{l}3.386 \\
3.397\end{array}$ & -0.011 & -0.057 & 0.477 \\
\hline
\end{tabular}

H8. Solar-consellers are more willing to be demand flexible than Non-owners.

H8 looks at differences in expressed willingness to be demand flexible between (co)owners of solar installations who have the possibility to consume as well as sell energy at the same time (Solar-consellers) and Non-owners. The ATT are jointly positive, meaning Solar-consellers have higher average means on the flexibility scale than Non-owners (Table 8). For the first dimension-the usage of household appliances, the ATT amounts to 0.909 scale points. In this instance, the $p$-value is reported to be below 0.001 , which corresponds to a highly significant result. For the charging of other electrical appliances, the mean difference is 0.442 . The $p$-value amounts to 0.073 and is slightly above the allowed error probability of 5 percent. The ATT for the charging electrical means of transportation is with 0.370 the smallest and with a $p$-value of 0.140 an insignificant result. Nevertheless, H8 can be partially confirmed. In this study, there is a significant difference in the willingness to be demand flexible between (co-)owners of solar installations and consumers who are not (co-)owners of RE production facilities when looking at the usage of household appliances.

Table 8. Demand flexibility comparisons of Solar-consellers (treated) versus Non-owners (controls) (source: authors' own calculations). Note: ${ }^{* \prime}$ s denote statistical significance levels ( ${ }^{* * *} 1$ percent; ${ }^{* *} 5$ percent).

\begin{tabular}{ccccccc}
\hline Dimension & Group & OBS & Mean & ATT & $t$-Value & $p$-Value \\
\hline \multirow{2}{*}{ Usage of household appliances } & Treated & 47 & 4.130 & \multirow{2}{*}{$0.909 * * *$} & 3.545 & $<0.001$ \\
& Controls & 191 & 3.222 & 3.356 & \multirow{2}{*}{0.442} & \multirow{2}{*}{0.0739} \\
\hline \multirow{2}{*}{ Charging electrical appliances } & Treated & 47 & 194 & 2.914 & \multirow{2}{*}{1.085} & 0.140 \\
& Controls & Treated & 47 & 3.538 & \multirow{2}{*}{0.370} & \\
\hline Charging electrical means & Controls & 162 & 3.169 & & & \\
\hline of transportation & & &
\end{tabular}

H9. Solar-sellers are more willing to be demand flexible than Non-owners.

With H9 the comparison between people who (co-)own solar installations and solely sell energy they produce from those installations (Solar-sellers) and Non-owners is undertaken. The former represents the treated and the latter the control group. The ATT show higher average mean differences in favor of the Solar-Sellers in all dimensions (Table 9). In detail, the ATT for the usage of household appliances is 0.193 . The mean difference for charging other electrical appliances is 0.136. Last, the difference in average means for electrical means of transportation amounts to 0.244 . Based on those results, there is a tendency that Solar-Sellers are more willing to be demand flexible than Non-owners. However, the reported results are utterly insignificant. Therefore, the H9 is rejected. In this 
analysis, there is no statistical differences in the willingness to be demand flexible between people who (co-)own solar facilities and people who are not involved with RE.

Table 9. Demand flexibility comparisons of Solar-sellers (treated) versus Non-owners (controls) (source: authors' own calculations).

\begin{tabular}{|c|c|c|c|c|c|c|}
\hline Dimension & Group & OBS & Mean & ATT & $t$-Value & $p$-Value \\
\hline Usage of household appliances & $\begin{array}{l}\text { Treated } \\
\text { Controls }\end{array}$ & $\begin{array}{c}43 \\
188\end{array}$ & $\begin{array}{l}3.810 \\
3.616\end{array}$ & 0.193 & 0.671 & 0.251 \\
\hline Charging electrical appliances & $\begin{array}{l}\text { Treated } \\
\text { Controls }\end{array}$ & $\begin{array}{c}43 \\
187\end{array}$ & $\begin{array}{l}3.262 \\
3.126\end{array}$ & 0.136 & 0.382 & 0.351 \\
\hline $\begin{array}{l}\text { Charging electrical means } \\
\text { of transportation }\end{array}$ & $\begin{array}{l}\text { Treated } \\
\text { Controls }\end{array}$ & $\begin{array}{c}43 \\
165\end{array}$ & $\begin{array}{l}3.722 \\
3.478\end{array}$ & 0.244 & 0.784 & 0.217 \\
\hline
\end{tabular}

H10. Solar-consellers are more willing to be demand flexible than Solar-consumers.

In the course of H10, Solar-Consellers (treated) are compared with Solar-Consumers (controls). With 1.242, the largest ATT reported so far occurs with the usage of household appliances (Table 10). This result is highly significant and holds an error probability below 1 percent. With the charging of other electrical appliances, the mean difference amounts to 0.685 scale points. However, in this instance, the corresponding $p$-value of 0.074 shows that this result is insignificant by a narrow margin. The last dimension-charging of other electrical appliances-yields an ATT of 0.584 and a $p$-value of 0.148 , an insignificant result as well. Following the presented results $\mathrm{H} 10$ can be partially confirmed. Electricity consumers who (co-)own solar energy production facilities are more willing to be demand flexible than consumers who (co-)own solar energy production facilities and solely consume the energy they produce. This, however, holds only true for the usage of household appliances.

Table 10. Demand flexibility comparisons of Solar-consellers (treated) versus Solar-consumers controls) (source: authors' own calculations). Note: ${ }^{* \prime}$ s denote statistical significance levels (*** 1 percent; ${ }^{* *} 5$ percent).

\begin{tabular}{|c|c|c|c|c|c|c|}
\hline Dimension & Group & OBS & Mean & ATT & $t$-Value & $p$-Value \\
\hline Usage of household appliances & $\begin{array}{l}\text { Treated } \\
\text { Controls }\end{array}$ & $\begin{array}{l}47 \\
39\end{array}$ & $\begin{array}{l}4.100 \\
2.858\end{array}$ & $1.242^{* * *}$ & 2.786 & 0.003 \\
\hline Charging electrical appliances & $\begin{array}{c}\text { Treated } \\
\text { Controls }\end{array}$ & $\begin{array}{l}47 \\
40 \\
\end{array}$ & $\begin{array}{l}3.410 \\
2.725\end{array}$ & 0.685 & 1.461 & 0.074 \\
\hline $\begin{array}{l}\text { Charging electrical means } \\
\text { of transportation }\end{array}$ & $\begin{array}{l}\text { Treated } \\
\text { Controls }\end{array}$ & $\begin{array}{l}47 \\
32\end{array}$ & $\begin{array}{l}3.412 \\
2.828\end{array}$ & 0.584 & 1.051 & 0.148 \\
\hline
\end{tabular}

H11. Solar-consellers are more willing to be demand flexible than Solar-sellers.

H11 compares the expressed demand flexibility of Solar-consellers (treated) and Solar-seller (controls). The ATT depicts a varying picture (Table 11). For the usage of household appliances, it amounts to 0.479 . In the case of the charging of other electrical appliances, an ATT of -0.153 is reported, meaning Solar-consellers are slightly less demand flexible than Solar-sellers. In the last analyzed dimension, the charging of electrical means of transportation, the average mean difference is 0.214 scale points in favor of the Solarconsellers. Nonetheless, the $\mathrm{t}$ - and corresponding $p$-values are insignificant for all treatment effects. Note that the number of controls, i.e., matched cases from the group of people that (co-)owns solar installations and solely sells produced energy, is rather small, with 13 to 16 . As mentioned earlier, the small and unequal group size poses the question of statistical power. Resulting shortcomings shall be part of the discussion of the results. For now, note that in this analysis no differences in demand flexibility were found for (co-)owners of solar installations which consume as well as sell and solely sell, respectively, energy they produce from those facilities. 
Table 11. Demand flexibility comparisons of Solar-consellers (treated) versus Solar-sellers controls) (source: authors' own calculations).

\begin{tabular}{|c|c|c|c|c|c|c|}
\hline Dimension & Group & OBS & Mean & ATT & $t$-Value & $p$-Value \\
\hline Usage of household appliances & $\begin{array}{l}\text { Treated } \\
\text { Controls }\end{array}$ & $\begin{array}{l}47 \\
16\end{array}$ & $\begin{array}{l}4.118 \\
3.639\end{array}$ & 0.479 & 0.604 & 0.274 \\
\hline Charging electrical appliances & $\begin{array}{l}\text { Treated } \\
\text { Controls }\end{array}$ & $\begin{array}{l}47 \\
16\end{array}$ & $\begin{array}{l}3.125 \\
3.278\end{array}$ & -0.153 & -0.218 & 0.414 \\
\hline $\begin{array}{l}\text { Charging electrical means } \\
\text { of transportation }\end{array}$ & $\begin{array}{l}\text { Treated } \\
\text { Controls }\end{array}$ & $\begin{array}{l}47 \\
13\end{array}$ & $\begin{array}{l}3.714 \\
3.500\end{array}$ & 0.214 & 0.297 & 0.384 \\
\hline
\end{tabular}

H12. Solar-sellers are more willing to be demand flexible than Solar-consumers.

The last hypothesis H12 looks at possible differences between Solar-sellers (treated) and Solar-consumers (controls). The ATT for the usage of household appliances is the only positive manifestation in this case and amounts to 0.028 (Table 12). The ATT for the charging of other electrical appliances as well as the charging of electrical means of transportation show that Solar-sellers tend to be less flexible than Solar-consumers and amount to -0.267 and -0.161 in the same order. Regardless of the respective directions, all mean differences are statistically insignificant. Similar to the previous hypothesis, H11, the number of observations for the controls is rather low. The associated weaknesses must be considered when interpreting the results. In any case, $\mathrm{H} 12$ must be entirely rejected in the context of this study. No significant differences in reported demand flexibility were found between (co-)owners of solar facilities who solely sell or, on the other hand, solely consume produced energy.

Table 12. Demand flexibility comparisons of Solar-sellers (treated) versus Solar-consumers (controls) (source: authors' own calculations).

\begin{tabular}{|c|c|c|c|c|c|c|}
\hline Dimension & Group & OBS & Mean & ATT & $t$-Value & $p$-Value \\
\hline \multirow{2}{*}{ Usage of household appliances } & Treated & 43 & 3.800 & \multirow{2}{*}{0.028} & \multirow{2}{*}{0.057} & \multirow{2}{*}{0.477} \\
\hline & Controls & 23 & 3.772 & & & \\
\hline \multirow{2}{*}{ Charging electrical appliances } & Treated & 43 & 3.300 & \multirow{2}{*}{-0.267} & \multirow{2}{*}{-0.461} & \multirow{2}{*}{0.323} \\
\hline & Controls & 24 & 3.567 & & & \\
\hline \multirow{2}{*}{$\begin{array}{l}\text { Charging electrical means } \\
\text { of transportation }\end{array}$} & Treated & 43 & 3.706 & \multirow{2}{*}{-0.161} & \multirow{2}{*}{-0.249} & \multirow{2}{*}{0.402} \\
\hline & Controls & 16 & 3.867 & & & \\
\hline
\end{tabular}

Summary H7-H12

$\mathrm{H} 7$ to $\mathrm{H} 12$ look at the expressed willingness to behave in a demand flexible manner within the group of (co-)owners of solar installations and compares them according to the usage possibility of produced energy and additionally considers electricity consumers who are not involved with RE. Ultimately, significant differences were found in two cases. First, H8 showed that (co-)owners of solar installations who consume and sell produced energy at the same time are more willing to be demand flexible than people who are not involved with RE. This, however, is solely holds true for the usage of household appliances. Second, in H10, a significant difference between prosumers of solar facilities that have the choice between self-consumption and sale and those who can solely self-consume was found. Again, this difference does only hold for the usage of general household appliances, such as a washing machine or a dishwasher. The applied matching technique caused small group sizes for $\mathrm{H} 11$ and $\mathrm{H} 12$, which has a destabilizing effect on the results that must be considered when interpreting the results. 


\section{Discussion}

When discussing the results of our analysis, two aspects should be deepened: First, the empirical results should be critically reviewed by analyzing further insights from the wider research field (e.g., energy consumption behavior in households in general). Second, limitations from a methodological point of view must be discussed.

For the former, the influence of various factors such as economic factors, social norms, an individual's attitude towards environmental concern, and the institutional setting an individual consumers' energy has been highlighted in several studies. Accordingly, our general finding that co-owners show a different energy consumption behavior is in line with previous studies that align social mechanisms inherent to (co-)ownership business models in the energy sector as with (co-)owners' willingness to show more demand flexibility $[7,30,38]$.

The reason for this is as follows: (Co-)investment usually leads to a deeper understanding of the issues related to the investment object. This improved awareness and knowledge is further reinforced in the context of energy infrastructures by the exchange with (co-)owners and consequently can serve as a catalyst for energy behavior change [63,64]; in the context of our study, the willingness to show flexible consumption behavior.

Regarding the behavioral differences between (co-)owners of different renewable energy technologies, the authors showed that the relationship between investment and involvement differs depending on the technology and that this difference also affects the willingness to engage in flexible consumption behavior. The (co-)owners of PV systems are usually located closer to the energy generation site and thus are likely show a greater involvement [65]. In contrast, the (co-)owners in our sample who invested in wind energy are likely to be located more distant from the turbine they have invested in than (co-)owners of PV installations. In these cases, (co-)ownership is likely to be perceived rather as a mere financial investment than an active means to participate in the energy sector [66]. Consequently, the impact of (co-)ownership on one's own behavior is lower and the willingness to behave flexibly is lower. However, a restriction is that the questionnaire did not explicitly ask about the spatial proximity so that the reasoning of this observation is a deductively derived conclusion that needs more empirical support.

Along the same line of argumentation is our interpretation of the observation that said relationship solely holds true for household appliances. This type of energy usage is an ubiquitous one that individual consumers will mostly understand with their relevant effects on energy consumption. Charging electrical appliances and, in particular, having a means of transportation in contrast is a preparatory stage and thus further away from the actual use, i.e., driving. With a more abstract relation to the actual use the planning of charging processes as part of becoming demand flexible thus require an extra cognitive effort. As various psychological factors are interlinked and play an important role for engagement [67] determining to a large extent whether an opportunity is seized or not the relation was expected to be stronger the closer it is to the actual use.

The observation of a significant difference between prosumers of solar facilities that have the choice between self-consumption and sale and those who can solely self-consume or are not involved with RE at all finally corroborates earlier findings [7] that only in the first case every kilowatt-hour not self-consumed becomes one potentially sold providing an intrinsic direct incentive for demand flexibility.

Regarding methodological aspects, this study is based on observational data from an online questionnaire. To contain the associated statistical biases, PSM was applied. The matching procedure is rooted in an homogenization of treatment and control groups based on observable characteristics that were part of the questionnaire. It is possible that further, unobserved characteristics which are not part of the econometric modeling procedure, could have an influence on the calculated propensity scores and thus impact mean differences between treatment and control group. As this study considered all main demographic features it is unlikely that significant estimators are overlooked. Nevertheless, to enhance the explanatory power of matching models in this context further field research 
is required to find out whether other characteristics should be considered when matching the different types of RE owners.

Further, the matching approach and the subdivision into different owner types as well as energy usage possibilities cause unequal and partly small sample sizes. Both have potential to destabilize the calculation of the ATT $[68,69]$. However, the applied bootstrap allows for mean comparisons with small or unequal samples and therefore is a reliable method to control for this circumstance [70,71]. Hesterberg [70] demonstrated the potential to yield robust results with a total sample of 30 observations. Nevertheless, any comparisons involving people who (co-)own a biogas plant do not yield sound results. Further, if the data would allow it, a subdivision according to the usage possibilities for people who (co-)own a biogas plant, or a wind turbine could have interesting implications. It is necessary to conduct further research where those groups are approached more targeted to increase the sample size.

\section{Conclusions}

This paper investigated whether (co-)ownership of consumers in RE infrastructures has effects on their willingness to adapt their consumption behavior, i.e., to become demandflexible and whether this effect differs across technologies (HA) and prosumption options (HB). Our analysis finds that HA is true: if consumers (co-)own a solar installation to produce RE they are generally more willing to show flexible energy consumption behavior. $\mathrm{HB}$ also holds true: when subdividing usage possibilities of produced RE within the group of people who (co-)own solar installations, only if both options, consumption and sale, are available a significant increase of the willingness to apply demand flexible behavior can be found. This distinction between the different scenarios (only auto-consumption/only sale/auto-consumption and sale) enables a more differentiated view allowing policy makers to tailor RE support measures.

In all cases, this only holds for household appliances. This is very likely due to the relationship between spatial proximity of (co-)owners to the infrastructure they own, the direct relationship to the actual use of the household appliance, and the resulting extent of involvement with energy related issues. This circumstance shows that generally the domain of household appliances solely, such as a washing machine or a dishwasher, is likely to be a viable option for demand flexibility approaches in a private context.

The results of our analysis are important in various ways. With a constantly rising share of RE in gross energy production, load management and grid stability become more and more important. Therefore, our findings can be used as a starting point for policymakers to support flexible consumption behavior through promoting (co-)ownership.

In concrete terms, first, the pending transposition of the Renewable Energy Directive (RED II) and here the privilege of Renewable Energy Communities (RECs) to share electricity and other forms of energy between members or shareholders, even when using the public grid are directly relevant. Our findings indicate that in RECs involving photovoltaic installations, electricity sharing concepts can rely on the support of their members in terms of behavioral changes towards a flexible consumption regarding household appliance. Projects involving other RES behavioral factors are expected to be more difficult to exploit, demanding a rather technological approach. Therefore, national legislators should take into account this functional context of RES production and reward this type of behavior-related social and local benefit by targeted incentives in the enabling framework.

Second, and more generally, our results can contribute to mitigating rebound effects in $\mathrm{RE}$ projects. The rebound effect describes the paradox that increased efficiency goes hand in hand with increased consumption. When applied to prosumership, increased savings from RE production lead the end user to the assumption that they are already saving enough energy/money, thus decreasing his/her willingness to adjust energy demand to production levels to save even more energy/money. This effect is exacerbated when one can only self-consume the produced energy, as storage may not be available or too expensive and sale to a third party is not an option, leading to a waste of excess production. 
Findings in the literature show that monetary gains such as potential bill savings often are not sufficient to promote flexible behavior and that other influences must also be addressed. This is in line with our observations stressing the importance of getting involved with one's consumption patterns, which is much more the case when consumer (co)-owners have the possibility to both, consume and sell the energy they produce, i.e., prosumership in the classical sense. Here, the relationship with spatial proximity to the RE installation and that with the direct use of electrical household appliances can indicate the direction both of future policy design and research projects. At the same time, our results prevent false expectations and will allow to calibrate support for energy efficiency programs and for RECs more targeted.

Author Contributions: Conceptualization, L.R., J.L. and Ö.Y.; methodology, L.R., J.L. and Ö.Y.; software, L.R.; validation, L.R. and Ö.Y.; formal analysis, L.R., J.L. and Ö.Y.; investigation, L.R. and J.L.; resources, L.R., J.L. and Ö.Y.; data curation, L.R.; writing-original draft preparation L.R., J.L. and Ö.Y.; writing-review and editing, L.R., J.L. and Ö.Y.; visualization, L.R.; supervision, L.R., J.L. and Ö.Y.; project administration, L.R.; funding acquisition, J.L. and Ö.Y. All authors have read and agreed to the published version of the manuscript.

Funding: The work on this paper has received support by the Kelso Institute for the Study of Economic Systems, the Horizon 2020 project "SCORE" grant agreement No 784960 and the Friedrich Naumann Foundation for Freedom.

Institutional Review Board Statement: Not applicable.

Informed Consent Statement: Informed consent was obtained from all subjects involved in the study.

Acknowledgments: The authors would like to thank Jörn Hagenguth and Hans Mörmann for their support at ImmobilienScout24. Further, the authors thank the Kelso-Team at the European University Viadrina for their support.

Conflicts of Interest: The authors declare no conflict of interest.

$\begin{array}{ll}\text { Abbreviations } \\ \text { ATT } & \text { Average Treatment Effect on the Treated } \\ \text { chi2 } & \text { Chi square } \\ \text { Coef. } & \text { Coefficients } \\ \text { Conf. } & \text { Confidence } \\ \text { Cons } & \text { Constant } \\ \text { DSM } & \text { demand side management } \\ \text { EE } & \text { energy efficiency } \\ \text { H } & \text { Hypothesis } \\ \text { Max } & \text { Maximum value } \\ \text { Min } & \text { Minimum value } \\ \text { NGO } & \text { non-governmental organization } \\ \text { OBS } & \text { observations } \\ \text { Prob } & \text { probability } \\ \text { PSM } & \text { propensity score matching } \\ \text { PV } & \text { photovoltaic } \\ \text { R2 } & \text { R square } \\ \text { RE } & \text { renewable energy } \\ \text { REC } & \text { Renewable Energy Communities } \\ \text { RED II } & \text { Renewable Energy Directive II } \\ \text { RES } & \text { renewable energy source } \\ \text { SCORE } & \text { Supporting Consumer Ownership in Renewable Energies } \\ \text { Std.Dev. } & \text { Standard Deviation } \\ \text { vRES } & \text { volatile renewable energy sources } \\ & \end{array}$


Appendix A. Questionnaire Flow

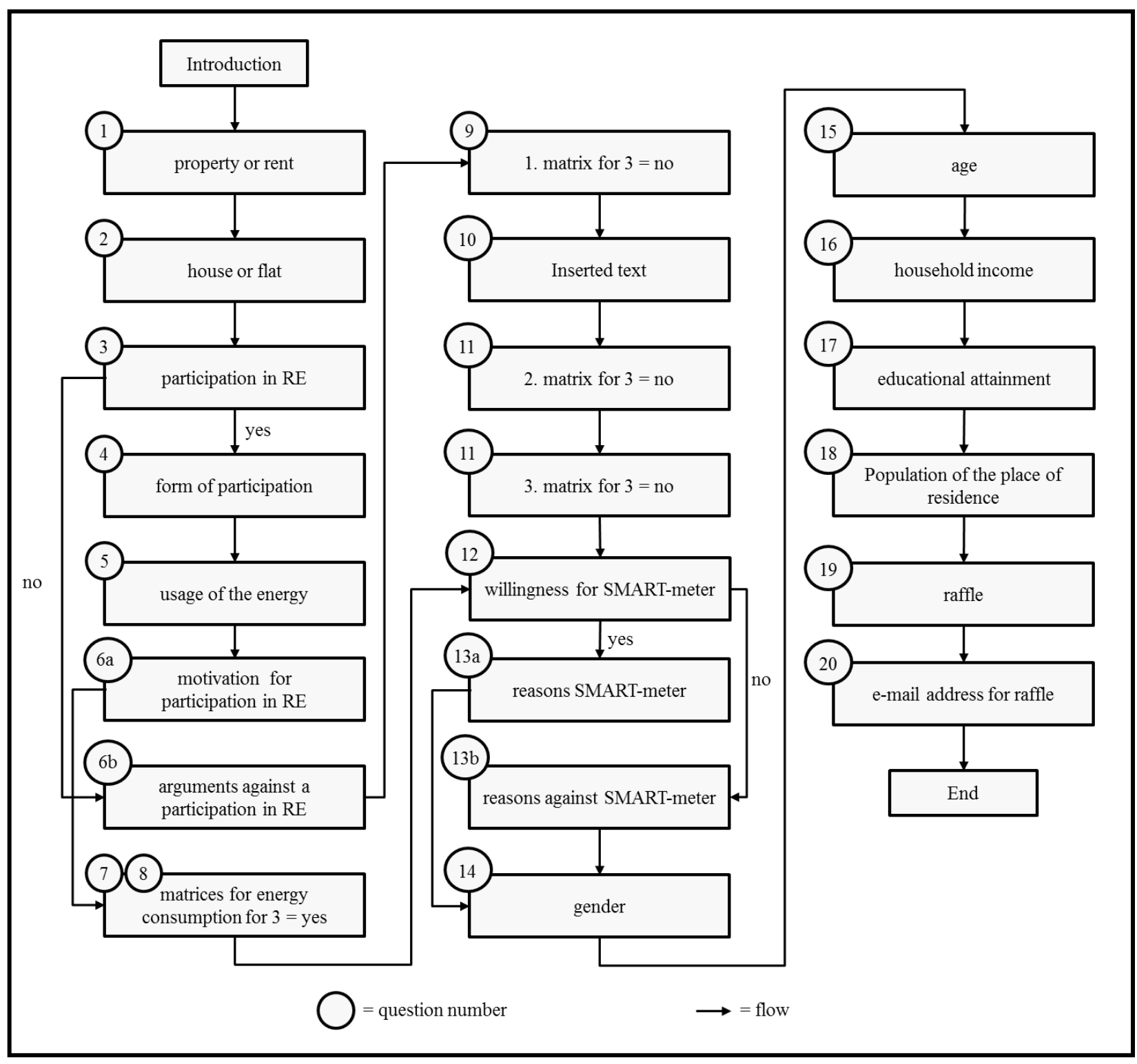

Figure A1. Questionnaire flow participants had to go through. 
Appendix B. Questionnaire Screenshots and Translation

\section{IMMOBILIEN}

SCOUT 24

\section{Umfrage zu erneuerbaren Energien}

Zunächst herzlichen Dank für thre Bereitschaft, an der Umfrage teilzunehmen. Diese Studie wird in Zusammenarbeit mit der Europa Universitāt Viadrina durchgeführt. Zweck dieser Umfrage ist es, vor dem Hintergrund der Energiewende einen Einblick zu Fragen der Büngerbeteiligung und der Flexibilisierung des Stromverbrauchs zu erhalten.

Thre Angaben werden anonymisiert ausgewertet, streng vertraulich behandelt und werden ausschlieBlich für Wissenschaftliche Zwecke genutzt.

Als kleines Dankeschon verlosen wir unter allen Teilnehmern, die den kompletten Fragebogen bis zum DD,MMYrYY ausfullen, 5 Amazon-Gutscheine im Wert von je 30 Euro.

Auf den folgenden Seiten werden Sie auf selbsterklärende Weise durch den elektronischen Fragebogen geführt. Kontaktmöglichkeiten für Rückfragen zur Umfrage oder der Thematik entnehmen Sie bitte der Einladungs-E-Mail zu dieser Umfrage.

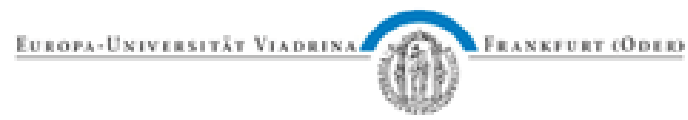

Figure A2. Screenshot of Questionnaire Page 1.

Renewable energy survey

First, thank you very much for your willingness to participate in the survey. This survey is conducted in cooperation with the European University Viadrina. The purpose of this survey is to gain insight into issues of citizen participation and the flexibilization of electricity consumption against the background of the energy transition.

Your data will be evaluated anonymously, treated as strictly confidential and will be used exclusively for scientific purposes.

As a small thank you, we will raffle 5 Amazon vouchers worth 30 Euros each among all participants who complete the entire questionnaire by the dd.mm.yyyy

On the following pages you will be guided through the electronic questionnaire in a self-explanatory way. Contact options for queries about the survey or the subject matter can be found in the invitation e-mail for this survey. 


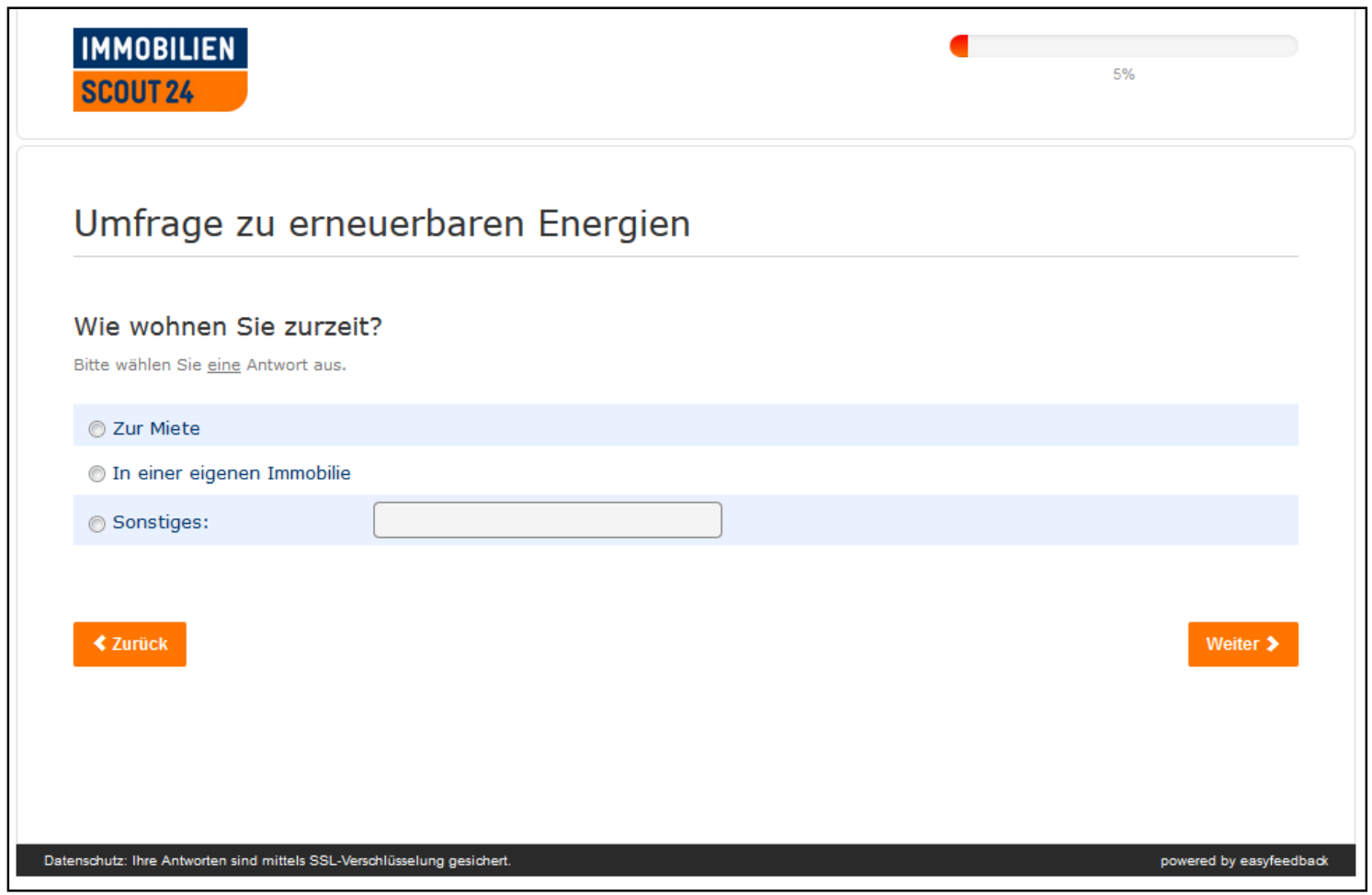

Figure A3. Screenshot of Questionnaire Page 2.

Where do you currently live?

Please select one single answer.

- Rental.

- In your own property.

- Other:

\section{IMMOBILIEN}

SCOUT 24

Umfrage zu erneuerbaren Energien

Wohnen Sie zurzeit in einem Haus oder einer Wohnung?

Bitte wählen Sie eine Antwort aus.

In einem Haus.

In einer Wohnung.

Sonstiges:

Figure A4. Screenshot of Questionnaire Page 3. 
Do you currently live in a house or a flat?

Please select one single answer.

- In a House.

- In a flat.

- Other:

IMMOBILIEN

SCOUT 24

\section{Umfrage zu erneuerbaren Energien}

Sind Sie in irgendeiner Form an der Erzeugung erneuerbarer Energien beteiligt?

Eine klassische Form der Beteiligung ist z.B. eine Solaranlage auf Ihrem Dach. Andere mögliche Beteiligungsformen wären

z.B. die Mitgliedschaft in einer Energiegenossenschaft oder Unternehmensanteile an anderen Geschäftsmodellen (z.B.

Bürgerwindparks) mit dem Zweck, sich an der Erzeugung erneuerbarer Energien zu beteiligen.

Bitte wählen Sie eine Antwort aus.

(2) Ja

Nein

Figure A5. Screenshot of Questionnaire Page 4.

Do you participate in any way in the production of energy from renewable sources? A classic form of participation is, for example, a solar installation on your roof. Other possible forms of participation would be, for example, membership in an energy cooperative or company shares in other business models (e.g., citizen wind farms) with the purpose of participating in the generation of renewable energies.

Please select one single answer.

- Yes.

- No. 
IMMOBILIEN

SCOUT 24

\section{Umfrage zu erneuerbaren Energien}

In welcher Form sind Sie an der Gewinnung erneuerbarer Energien beteiligt?

Bitte wählen Sie eine oder mehrere Antworten aus und machen Sie gegebenenfalls fehlende Angaben.

Ich bin (Mit-)Eigentümer einer Solaranlage.

$\square$ Ich bin (Mit-)Eigentümer eines Windrads.

$\square$ Ich bin (Mit-)Eigentümer einer Biogasanlage.

$\square$ Sonstiges; Ich bin (Mit-)Eigentümer: ...

Figure A6. Screenshot of Questionnaire Page 5.

In which way do you participate in the production of energy from renewable sources? Please select one or more answers and fill in any missing information.

- I am (co-)owner of a solar power plant.

- I am (co-)owner of a wind turbine.

- I am (co-)owner of a biogas power plant

- I am (co-)owner of a: [user input]

\section{IMMOBILIEN}

SCOUT 24

\section{Umfrage zu erneuerbaren Energien}

Wie nutzen Sie die so gewonnene Energie?

Bitte wählen Sie eine Antwort aus.

Ausschließlich für den Eigenverbrauch

Eigenverbrauch und Verkauf der erzeugten Energie

Ausschließlicher Verkauf der erzeugten Energie (bzw. Weiterverkauf durch eine dritte Partei) 
How do you use the energy generated by your installation(s)? Please select one single answer.

- Solely for own consumption

- Own consumption and sale of the generated energy

- Solely sale of the generated energy (e.g., through a third party)

IMMOBILIEN

SCOUT 24

\section{Umfrage zu erneuerbaren Energien}

Was motivierte Sie, sich an der Erzeugung erneuerbarer Energien zu beteiligen?

Bitte wählen Sie eine oder mehrer Antworten aus und machen Sie gegebenenfalls fehlende Angaben.

$\square$ attraktive Alternative zu klassischen Anlagemöglichkeiten

$\square$ niedrige Beitrittshürden (z.B. Beteiligung mit geringen Geldbeträgen möglich oder geringer formaler Aufwand)

$\square$ Senkung der Energiekosten

$\square$ (teilweise) Unabhängigkeit von Entwicklungen des Strompreises

$\square$ Beitrag zur regionalen Wertschöpfung / Stärkung der regionalen Wirtschaft

$\square$ Beitrag zum Umweltschutz

$\square$ Begrenzung der Marktmacht großer Energieversorger

$\square$ räumliche Nähe zu einem Projekt in Verbindung mit erneuerbaren Energien

$\square$ Wunsch nach Mitgestaltung (lokaler) Energiepolitik

D positive Erfahrungen von Verwandten / Bekannten mit Projekten dieser Art

$\square$ sonstiges:

Figure A8. Screenshot of Questionnaire Page 7.

What motivated you to participate in renewable energy generation? Please select one or more answers and fill in any missing information.

- Attractive alternative to classic investment opportunities

- Low entry barriers (e.g., participation with small amounts of money possible or low formal effort)

- Reduction of energy costs

- (Partial) independence from electricity price developments

- Contribution to regional value creation/strengthening of regional economy

- Contribution to environmental protection

- Limitation of the market power of large energy suppliers

- Spatial proximity to a project in connection with renewable energies

- Desire to participate in shaping (local) energy policy

- Positive experiences of relatives/acquaintances with projects of this kind

- Other: 


\section{IMMOBILIEN}

SCOUT 24

\section{Umfrage zu erneuerbaren Energien}

Im folgenden Fragenblock sollen Sie abwägen, inwiefern Sie bereit sind Ihren Energieverbrauch an Ihre Energieproduktion anzupassen. Beurteilen Sie dazu bitte, in welchem Maße Sie bestimmte Tätigkeiten nur ausüben, wenn der Anteil Ihrer eigens produzierten Energie Ihren Stromverbrauch so gut wie möglich abdeckt (Produktionsspitzen).

(Sie können Ihre Antworten dabei zwischen 1 für "Ich stimme überhaupt nicht zu." und 5 "Ich stimme voll und ganz zu." abstufen.)

Ich bin bereit...

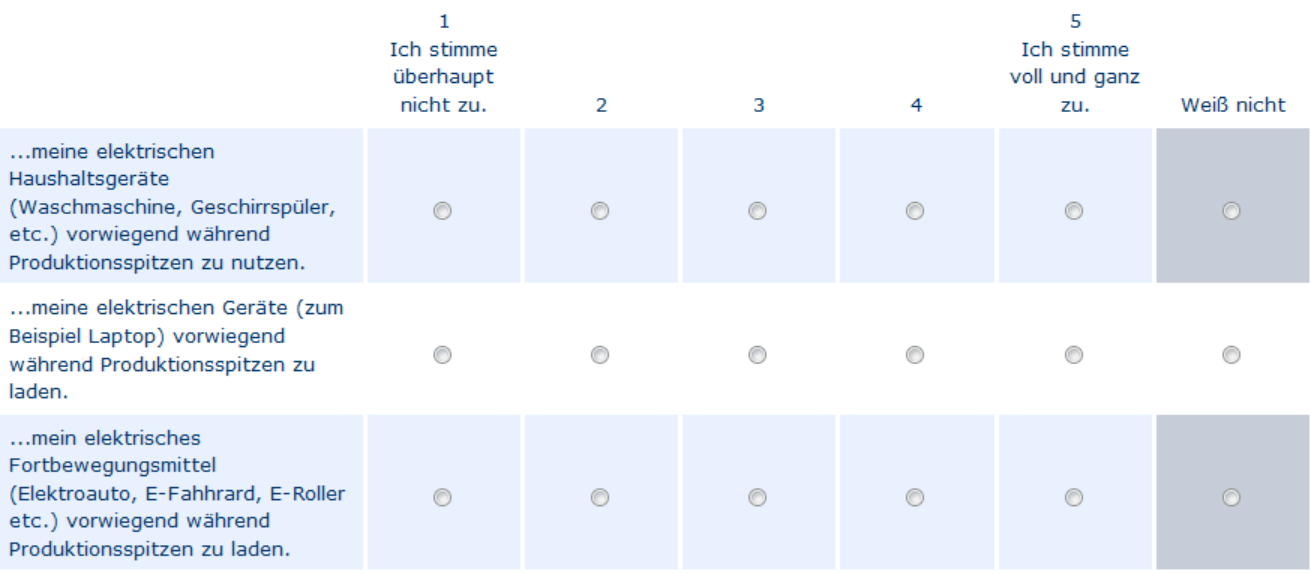

Figure A9. Screenshot of Questionnaire Page 8.

In the following block of questions, you are asked to consider to what extent you are willing to adapt your energy consumption to your energy production. For this purpose, please assess to what extent you would only perform certain activities when the share of your own produced energy covers your electricity consumption as much as possible (production peaks).

(You can grade your answers between 1 for "I do not agree at all" and 5 for "I agree completely". You can also choose "Do not know".)

I am willing to ...

- $\quad$... use household appliances (e.g., washing machine, dishwasher, etc.) mainly when the share of electricity from renewable sources in the grid is very high.

- $\quad$... recharge electrical devices (e.g., laptop) mainly when the share of electricity from renewable sources in the grid is very high.

- $\quad$... recharge electrical means of transportation (e.g., electric car/scooter/bike) mainly when the share of electricity from renewable sources in the grid is very high. 


\section{IMMOBILIEN}

SCOUT 24

\section{Umfrage zu erneuerbaren Energien}

Stellen Sie sich nun bitte vor, Sie würden die aus Ihrer Beteiligung an erneuerbaren Energien gewonnene Energie in Ihrem privaten Haushalt direkt verbrauchen. Inwieweit wären Sie dann bereit, Ihren Energieverbrauch an Ihre eigene Energieproduktion anzupassen? Beurteilen Sie dazu bitte, in welchem Maße Sie bestimmte Tätigkeiten nur ausüben würden, wenn der Anteil Ihrer eigens produzierten Energie Ihren Stromverbrauch so gut wie möglich abdeckt (Produktionsspitzen).

(Sie können Ihre Antworten dabei zwischen 1 für „ICh stimme überhaupt nicht zu." und 5 "Ich stimme voll und ganz zu." abstufen.)

Ich wäre bereit..

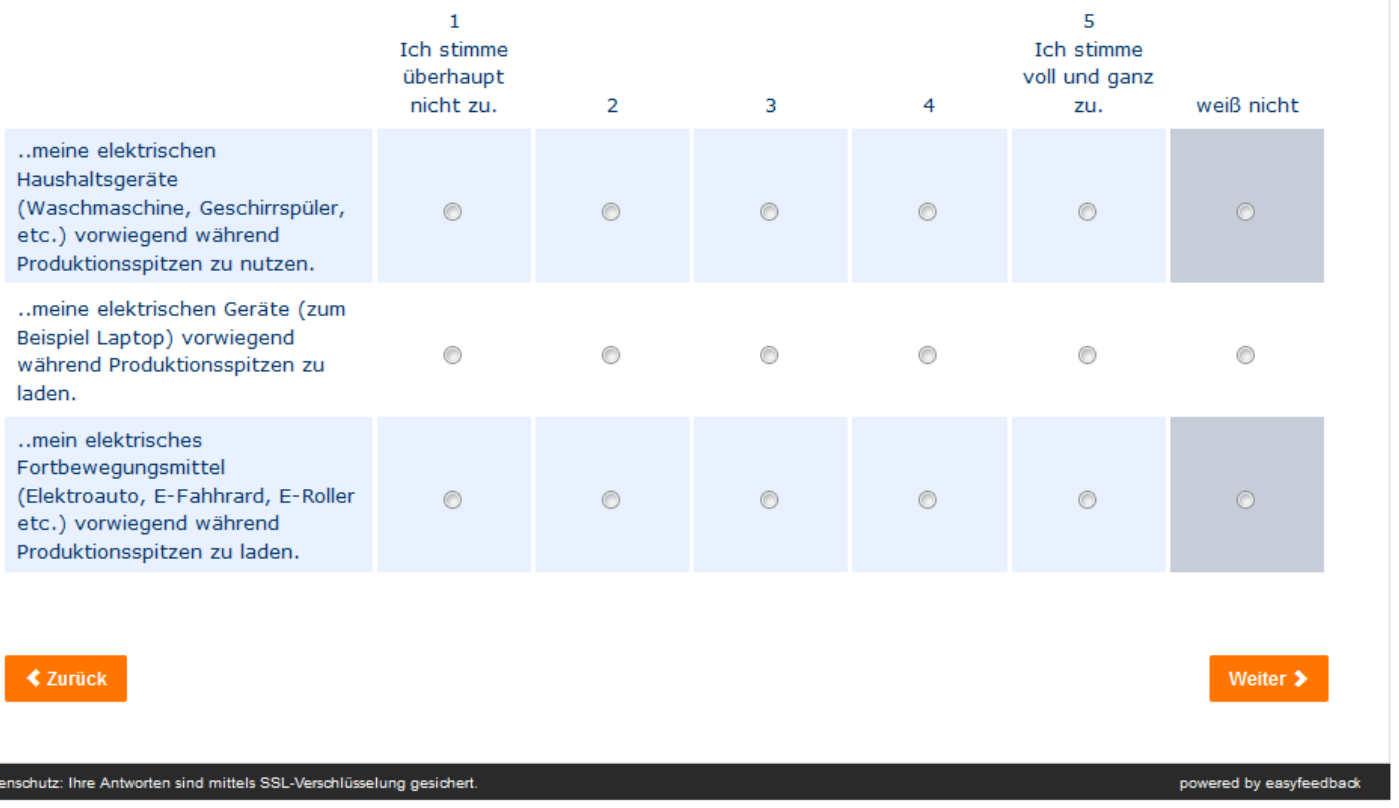

Figure A10. Screenshot of Questionnaire Page 9.

Now please imagine that you would directly consume the energy generated from your renewable energy participation in your private household.

To what extent would you then be willing to adapt your energy consumption to your own energy production?

Please assess to what extent you would only carry out certain activities if the share of your own produced energy covered your electricity consumption as much as possible (production peaks).

(You can grade your answers between 1 for "I do not agree at all" and 5 for "I agree completely". You can also choose "Do not know".)

I am willing to ...

- $\quad$... use household appliances (e.g., washing machine, dishwasher, etc.) mainly when the share of electricity from renewable sources in the grid is very high.

- $\quad$... recharge electrical devices (e.g., laptop) mainly when the share of electricity from renewable sources in the grid is very high.

- $\quad$... recharge electrical means of transportation (e.g., electric car/scooter/bike) mainly when the share of electricity from renewable sources in the grid is very high. 
IMMOBILIEN

SCOUT 24

\section{Umfrage zu erneuerbaren Energien}

In Deutschland hat der Strom, der aus erneuerbaren Energien gewonnen wird (insbesondere Biogasanlagen, Solaranlagen und Windkrafträdern) bei der Einspeisung in das Stromnetz immer Vorrang vor dem Strom, der aus fossilen Energieträgern produziert wurde. Dies hat zur Folge, dass der Anteil des Stroms aus erneuerbaren Energien im Stromnetz dann besonders hoch ist, wenn die Sonne scheint bzw. höhere Windstärken vorliegen.

Inwieweit sind Sie vor diesem Hintergrund bereit, Ihren Energieverbrauch an den Anteil der erneuerbaren Energie im allgemeinen Stromnetz anzupassen? Beurteilen Sie dazu bitte, in welchem Maße Sie bestimmte Tätigkeiten nur ausüben würden, wenn der Anteil des Stroms aus erneuerbaren Energien in unserem Stromnetz besonders hoch ist (wenn z.B. die Sonne scheint oder starker Wind vorliegt).

(Sie können Ihre Antworten dabei zwischen 1 für "Ich stimme überhaupt nicht zu." und 5 „Ich stimme voll und ganz zu." abstufen.)

Ich wäre bereit..

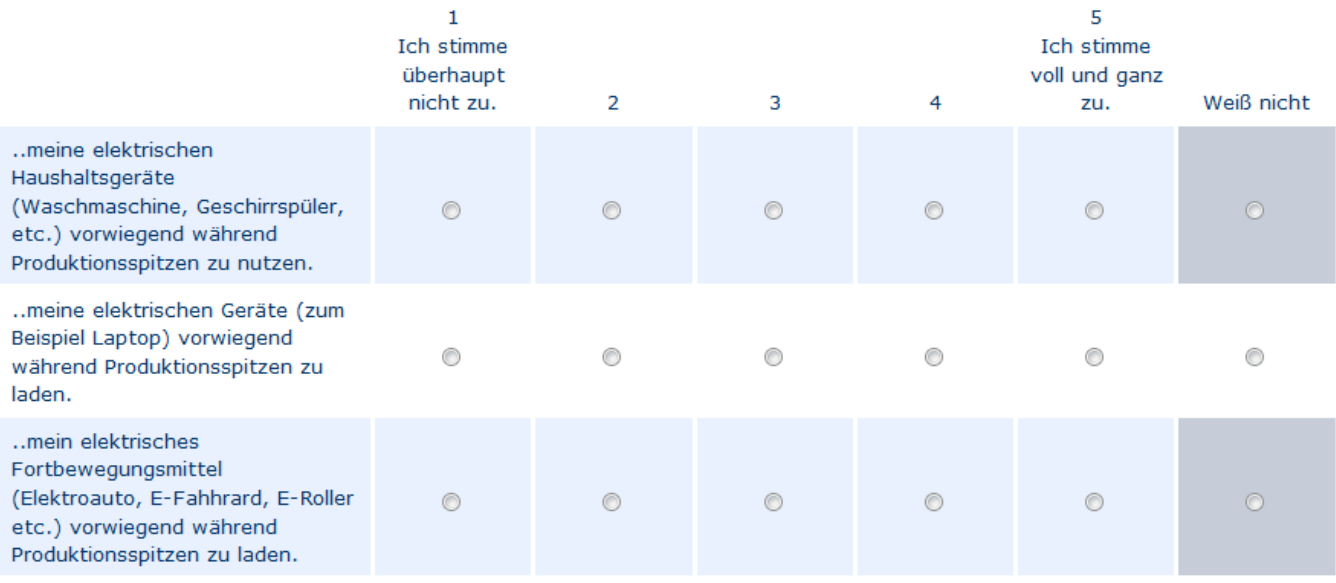

Figure A11. Screenshot of Questionnaire Page 10.

In Germany, electricity generated from renewable sources (especially biogas plants, solar panels, and wind turbines) always has priority over electricity produced from fossil fuels when it is fed into the grid. As a result, the share of electricity from renewable energies in the power grid is particularly high when the sun is shining or there are higher wind strengths.

Against this background, to what extent are you prepared to adjust your energy consumption to the share of renewable energy in the general power grid?

Please assess to what extent you would only carry out certain activities if the share of electricity from renewable energies in our power grid is particularly high (e.g., if the sun is shining or there is strong wind).

(You can grade your answers between 1 for "I do not agree at all" and 5 for "I agree completely". You can also choose "Do not know".)

I am willing to ... 
- $\quad$... use household appliances (e.g., washing machine, dishwasher, etc.) mainly when the share of electricity from renewable sources in the grid is very high.

- $\quad$... recharge electrical devices (e.g., laptop) mainly when the share of electricity from renewable sources in the grid is very high.

- ... recharge electrical means of transportation (e.g., electric car/scooter/bike) mainly when the share of electricity from renewable sources in the grid is very high.

\section{IMMOBILIEN}

\section{SCOUT 24}

\section{Umfrage zu erneuerbaren Energien}

Stellen Sie sich nun bitte vor, Sie wären direkt an der Produktion von erneuerbarer Energie in Form einer Solar- oder Windkraftanlage beteiligt (zum Beispiel ein Windrad im Garten). Die daraus gewonnene Energie nutzen Sie ausschließlich für Ihren eigenen Haushalt.

Inwieweit wären Sie vor diesem Hintergrund bereit, Ihren Energieverbrauch an Ihre eigene Energieproduktion anzupassen.

(Sie können Ihre Antworten dabei zwischen 1 für "Ich stimme überhaupt nicht zu." und 5 "Ich stimme voll und ganz zu." abstufen.)

Ich wäre bereit.

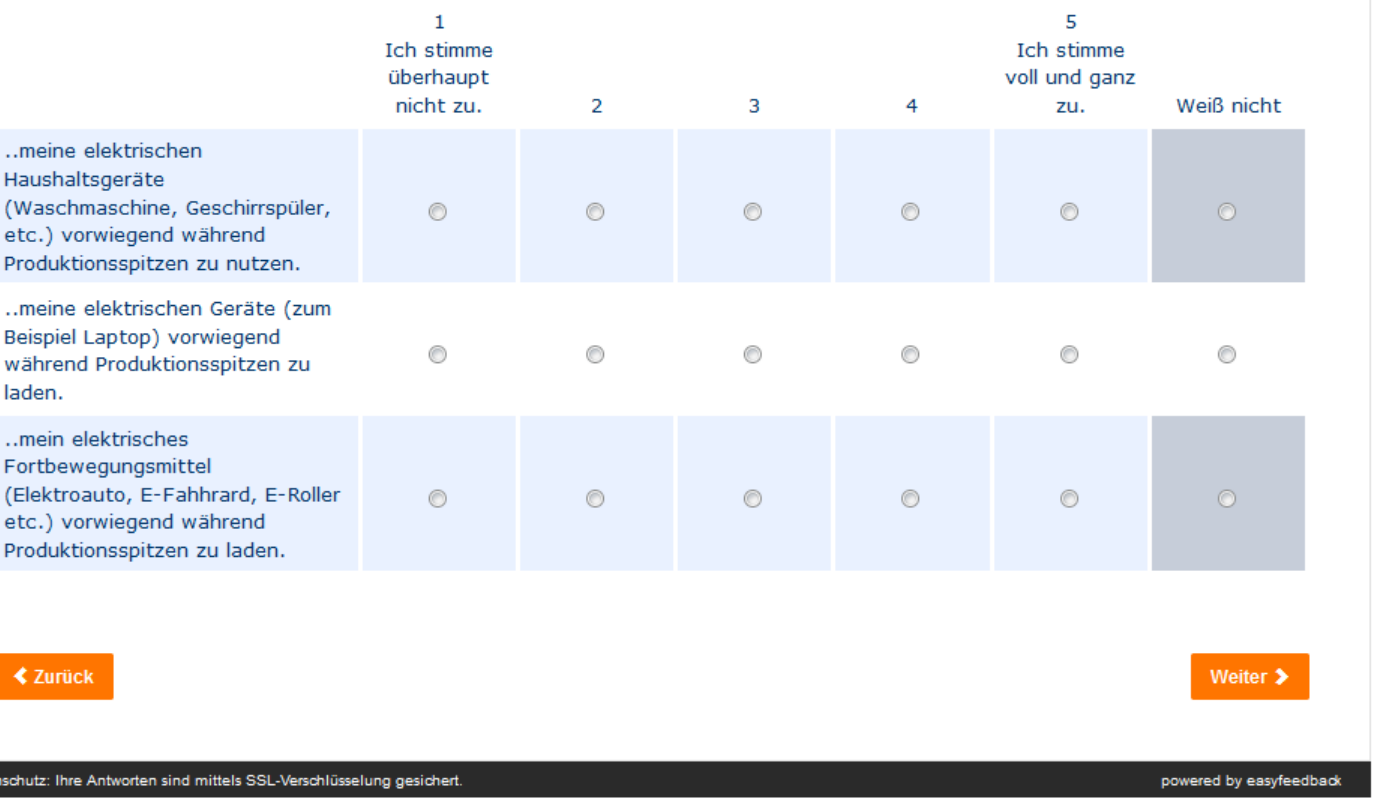

Figure A12. Screenshot of Questionnaire Page 11.

Now please imagine that you are directly involved in the production of renewable energy in the form of a solar or wind power plant (e.g., a wind turbine in your backyard). You use the energy generated from this exclusively for your own household.

Against this background, to what extent would you be willing to adapt your energy consumption to your own energy production?

(You can grade your answers between 1 for "I do not agree at all" and 5 for "I agree completely". You can also choose "Do not know".)

I am willing...

- $\quad$... to use my household electrical appliances (washing machine, dishwasher, etc.) mainly during production peaks. 
- $\quad$... to charge my electrical devices (e.g., laptop) mainly during production peaks.

- $\quad .$. to charge my electronic means of transportation (electric car, e-bike, e-scooter etc.) mainly during production peaks.

\section{IMMOBILIEN}

SCOUT 24

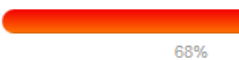

\section{Umfrage zu erneuerbaren Energien}

Nun verändert sich die Situation noch einmal leicht. Stellen Sie sich bitte weiterhin vor, dass Sie an der Produktion von Strom aus erneuerbaren Energien beteiligt sind. Sie nutzen diesen jedoch nicht nur für Ihren eigenen Haushalt, sondern können, wenn Sie mehr produzieren als Sie verbrauchen, den zusätzlichen Strom an Dritte verkaufen. Der Verkauf würde ab dem Zeitpunkt einer Überproduktion automatisch stattfinden - es würde kein weiterer Aufwand für Sie entstehen.

Inwieweit wären Sie bereit, Ihren Energieverbrauch an Ihre Energieproduktion anzupassen, um neben der Versorgung des eigenen Haushalts noch Geld mit dem Verkauf von Strom zu verdienen.

(Sie können Ihre Antworten dabei zwischen 1 für "Ich stimme überhaupt nicht zu." und 5 "Ich stimme voll und ganz zu." abstufen.)

Ich wäre bereit..

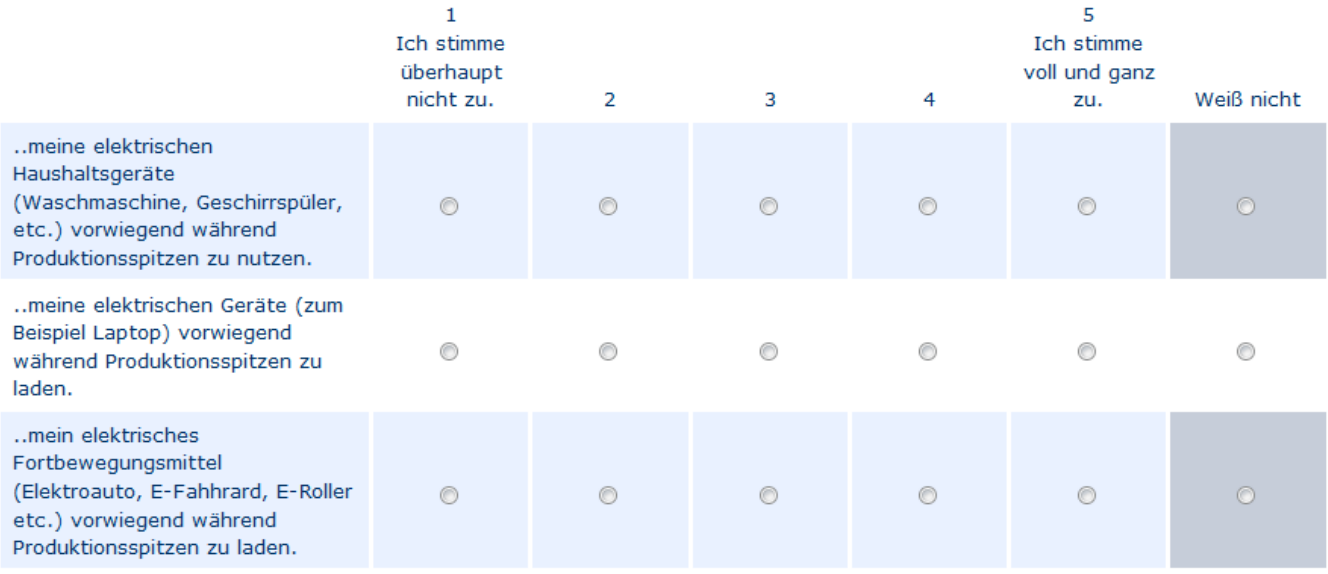

Figure A13. Screenshot of Questionnaire Page 12.

Now the situation changes slightly once again. Please continue to imagine that you are involved in the production of electricity from renewable sources. However, you not only use this for your own household, but if you produce more than you consume, you can sell the additional electricity to third parties. The sale would take place automatically from the moment of excess production. There would be no further effort on your part.

To what extent would you be willing to adjust your energy consumption to your energy production in order to earn money from selling electricity, in addition to supplying your own household?

(You can grade your answers between 1 for "I do not agree at all" and 5 for "I agree completely". You can also choose "Do not know".) 
I am willing to ...

- ... use my household electrical appliances (washing machine, dishwasher, etc.) mainly during production peaks.

- $\quad$... charge my electrical devices (e.g., laptop) mainly during production peaks

- $\quad .$. charge my electronic means of transportation (electric car, e-bike, e-scooter etc.) mainly during production peaks.

In order to efficiently manage the energy consumption of a private household, electricity providers offer the installation of a so-called "smart meter". This smart meter monitors your electricity consumption and is able to automatically adjust it to your consumption. Thus, it allows for an automated adjustment of your energy consumption to times when the share of renewable energies in the grid is particularly high.

Would you be willing to have such a smart meter installed in your household, even if it meant one-time financial expenses for you?

You can grade your answer between 1 for "I would never be prepared to do this" and 7 for "I would be prepared to do this in any case". You can also choose "Do not know".

\section{IMMOBILIEN}

\section{Umfrage zu erneuerbaren Energien}

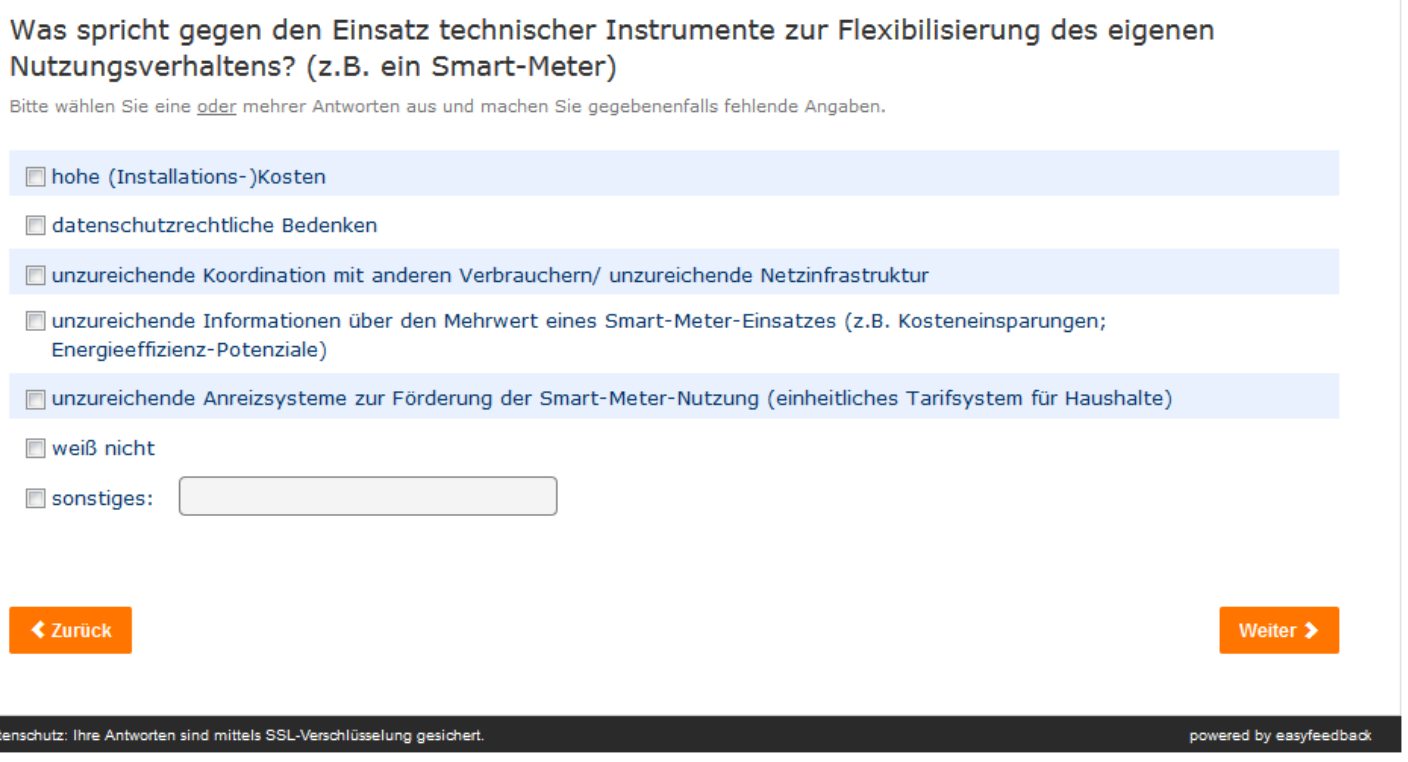

Figure A14. Screenshot of Questionnaire Page 13.

What are the arguments against the use of technical instruments to make one's own usage behavior more flexible (e.g., a smart meter)?

Please select one or more answers and fill in any missing information.

- High (installation) costs

- Data protection concerns

- Insufficient coordination with other consumers/insufficient network infrastructure

- Insufficient information about the added value of smart meter deployment (e.g., cost savings, energy efficiency potential)

- I do not know

- Other: 
IMMOBILIEN

SCOUT 24

\section{Umfrage zu erneuerbaren Energien}

Welche Eigenschaften sollten technische Instrumente haben, um Sie bei der Flexibilisierung Ihres Stromverbrauchs zu unterstützen (z.B. ein Smart-Meter)?

Bitte wählen Sie eine oder mehrer Antworten aus und machen Sie gegebenenfalls fehlende Angaben.

$\square$ detaillierte Anzeige von Verbrauch, produzierter Strommenge und Stromkosten

$\square$ Erleichterung von Abrechnungsprozessen (z.B. Fernablesen durch Anbieter)

$\square$ Flexibilisierung von Abrechnungsschemata (z.B. monatsgenaue Abrechnung)

$\square$ Analyse der eigenen Verbrauchsdaten / Erstellung eines Verbrauchsprofils

$\square$ (anonymisierte) Vergleiche mit anderen Nutzern als Benchmarking

Möglichkeit der automatischen / ferngesteuerten Einschaltung von Haushaltsgeräten in Abhängigkeit von Produktionsschwankungen (oder in Abwesenheit, z.B. während der Urlaubszeit)

$\square$ weiß nicht

$\square$ sonstiges:

Figure A15. Screenshot of Questionnaire Page 14.

What characteristics should technical instruments have to support you in making your electricity consumption more flexible (e.g., a smart meter)?

Please select one or more answers and fill in any missing information.

- Detailed display of consumption, amount of electricity produced and electricity costs

- $\quad$ Facilitation of billing processes (e.g., remote reading by suppliers)

- $\quad$ Flexibilization of billing schemes (e.g., monthly billing)

- Analysis of own consumption data/creation of a consumption profile

- (Anonymized comparisons with other users as benchmarking

- Possibility of automatic/remote controlled switching on of household appliances depending on production fluctuations (or in absence, e.g., during vacation time)

- I do not know

- Other: 
IMMOBILIEN

SCOUT 24

\section{Umfrage zu erneuerbaren Energien}

Bitte geben Sie Ihr Geschlecht an.

Bitte wählen Sie eine Antwort aus.

Männlich

Weiblich

Wie alt sind Sie?

Bitte wählen Sie eine Antwort aus.

Hat Ihr Haushalt ein eigenes Einkommen?

Bitte wählen Sie eine Antwort aus (optional).

○a, unter 500 Euro netto / Monat

Ja, zwischen 500 und 1000 Euro netto/Monat

Ja, zwischen 1001 und 2000 Euro netto/Monat

Ja, zwischen 2001 und 3000 Euro netto/Monat

$\bigcirc \mathrm{Ja}$, zwischen 3001 und 4000 Euro netto/Monat

Ja, zwischen 4001 und 5000 Euro netto/Monat

Ja, über 5000 Euro netto/Monat

Nein

$\checkmark$ Keine Angabe

Figure A16. Screenshot of Questionnaire Page 15.

Please indicate your gender.

Please select one single answer.

- Male

- Female

How old are you?

Please select one single answer.

Does your household have its own income?

Please select one single answer (optional).

- Yes under 500 euro/month

- Yes between 500 and 1000 euro net/month

- Yes between 1001 and 2000 euro net/month

- Yes between 2001 and 3000 euro net/month

- Yes between 3001 and 4000 euro net/month

- Yes between 4001 and 5000 euro net/month

- Yes over 5000 euro net/month

- No

- Prefer not to say 
IMMOBILIEN

SCOUT 24

\section{Umfrage zu erneuerbaren Energien}

Was ist Ihr höchster erreichter Bildungsabschluss?

Bitte wählen Sie eine Antwort aus.

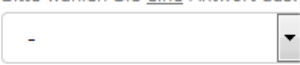

Keine Angabe

Wie viele Einwohner hat Ihr Wohnort ungefähr?

Bitte wählen Sie eine Antwort aus.

-

$\checkmark$ Weiß nicht

Figure A17. Screenshot of Questionnaire Page 16.

What is your highest educational attainment?

Please select one single answer.

Prefer not to say

Approximately how many inhabitants does your place of residence have? Please select one single answer.

Do not know.

IMMOBILIEN

SCOUT 24

\section{Umfrage zu erneuerbaren Energien}

Wollen Sie an der Verlosung der Amazon-Gutscheine teilnehmen?

Ja $\bigcirc$ Nein

Wenn Sie an der Verlosung der Amazon-Gutscheine teilnehmen wollen, geben Sie bitte Ihre E-Mailadresse an. Sollten Sie kein Interesse an unserem Gewinnspiel haben, überspringen Sie diese Frage einfach.

Meine E-Mailadresse lautet:

Ja, ich akzeptiere die Teilnahmebedingungen.

Figure A18. Screenshot of Questionnaire Page 17. 
Do you want to participate in the raffle of Amazon vouchers?

Yes No

If you want to participate in the raffle of the Amazon vouchers, please enter your e-mail address. If you are not interested in our raffle, simply skip this question.

My e-mail address is:

Yes, I accept the conditions of participation.

\section{IMMOBILIEN}

\section{SCOUT 24}

\section{Umfrage zu erneuerbaren Energien}

Vielen Dank für Ihre Teilnahme!

Sie haben die Umfrage erfolgreich beendet. Sie können das Browserfenster jetzt schließen.

Figure A19. Screenshot of Questionnaire Page 18.

Thank you for your participation!

You have successfully completed the survey.

You can close the browser window now.

\section{Appendix C}

\section{Data Summary}

Table A1. Depiction of summarized data used to produce results (source: authors' own calculations).

\begin{tabular}{cccccc}
\hline Variable & Obs & Mean & Std.Dev. & Min & Max \\
\hline participation & 2074 & 1.873 & 0.333 & 1 & 2 \\
usage & 264 & 1.693 & 0.823 & 1 & 3 \\
group & 2074 & 0.143 & 0.4 & 0 & 3 \\
age & 1978 & 4.616 & 1.416 & 1 & 7 \\
income & 1855 & 4.698 & 1.61 & 1 & 8 \\
education & 1934 & 3.56 & 1.472 & 1 & 6 \\
population & 1913 & 3.832 & 1.626 & 1 & 6 \\
gender & 1954 & 0.403 & 0.491 & 0 & 1 \\
df_household & 1994 & 3.483 & 1.391 & 1 & 5 \\
df_electrical & 2006 & 3.061 & 1.481 & 1 & 5 \\
df_transport & 1700 & 3.439 & 1.482 & 1 & 5 \\
participation & 2074 & 1.873 & 0.333 & 1 & 2 \\
\hline
\end{tabular}




\section{Codebook}

Table A2. Depiction of variable names, labels and values for all variables used to produce the results.

\begin{tabular}{|c|c|c|c|c|c|c|c|c|c|c|c|c|c|}
\hline Variable & Label & \multicolumn{12}{|c|}{ Values } \\
\hline participation & (Co-) owner in RE & \multicolumn{6}{|c|}{1 yes } & \multicolumn{6}{|c|}{2 no } \\
\hline usage & $\begin{array}{c}\text { Usage option for produced } \\
\text { energy }\end{array}$ & \multicolumn{4}{|c|}{1 solely self-consumption } & \multicolumn{4}{|c|}{$\begin{array}{c}2 \\
\text { consumption \& sale }\end{array}$} & \multicolumn{4}{|c|}{$\begin{array}{c}3 \\
\text { solely sale } \\
\end{array}$} \\
\hline group & RE technology & \multicolumn{3}{|c|}{0 Non-owner } & \multicolumn{3}{|c|}{ 1 Solar-owner } & \multicolumn{3}{|c|}{2 Wind-owner } & \multicolumn{3}{|c|}{3 Biogas-owner } \\
\hline age & Age of participant & 1 under 18 & \multicolumn{2}{|r|}{$218-28$} & \multicolumn{2}{|c|}{$329-35$} & 436 & -45 & \multicolumn{2}{|c|}{$546-55$} & \multicolumn{2}{|r|}{$656-65$} & 7 over 65 \\
\hline income & Income of household & $\begin{array}{c:c}1 \text { no } & \\
\text { income } & \mathrm{v}\end{array}$ & \multicolumn{2}{|c|}{$\begin{array}{c}2 \\
\text { under } 500\end{array}$} & 3 & \multicolumn{2}{|c|}{$\begin{array}{c}41.001- \\
2.000\end{array}$} & \multicolumn{2}{|c|}{$\begin{array}{c}52.001- \\
3.000\end{array}$} & \multicolumn{2}{|c|}{$\begin{array}{c}63.001- \\
4.000\end{array}$} & $\begin{array}{c}74.001- \\
5.000\end{array}$ & $\begin{array}{c}8 \text { more } \\
\text { than } 5.000 \\
\end{array}$ \\
\hline population & $\begin{array}{l}\text { population of the } \\
\text { city/village of the } \\
\text { participant }\end{array}$ & 11.000 or $1 \mathrm{e}$ & & $21.001-10$ & 0.000 & \multicolumn{2}{|c|}{$\begin{array}{l}310.001- \\
50.000\end{array}$} & \multicolumn{2}{|c|}{$\begin{array}{c}450.001- \\
100.000\end{array}$} & \multicolumn{3}{|c|}{$\begin{array}{c}5100.001- \\
500.000\end{array}$} & $\begin{array}{c}6 \text { more than } \\
500.000\end{array}$ \\
\hline gender & Gender of participant & \multicolumn{6}{|c|}{0 male } & \multicolumn{6}{|c|}{1 female } \\
\hline education & $\begin{array}{c}\text { Educational achievement } \\
\text { of participant }\end{array}$ & $\begin{array}{l}0 \text { no official } \\
\text { education }\end{array}$ & \multicolumn{2}{|c|}{1 O-level } & \multicolumn{2}{|c|}{$\begin{array}{c}2 \\
\text { matriculatio } \\
\text { n standard }\end{array}$} & $\begin{array}{r}\quad \\
\mathrm{h}\end{array}$ & $\begin{array}{l:l} & 4 \\
\text { ntices } & \\
\mathrm{p}\end{array}$ & \multicolumn{2}{|c|}{\begin{tabular}{|c|c|}
4 university \\
of applied \\
sciences \\
degree
\end{tabular}} & \multicolumn{2}{|c|}{$\begin{array}{c}5 \text { university } \\
\text { degree }\end{array}$} & $6 \mathrm{PhD}$ \\
\hline df_household & $\begin{array}{l}\text { Demand flexibility - } \\
\text { Household appliances }\end{array}$ & \multicolumn{2}{|c|}{$\begin{array}{c}1 \text { strongly } \\
\text { disagree }\end{array}$} & \multicolumn{3}{|c|}{2 disagree } & \multicolumn{2}{|c|}{3 undecided } & \multicolumn{3}{|c|}{4 agree } & \multicolumn{2}{|c|}{5 strongly agree } \\
\hline df_electrical & $\begin{array}{l}\text { Demand flexibility - } \\
\text { electrical appliances }\end{array}$ & \multicolumn{2}{|c|}{$\begin{array}{c}1 \text { strongly } \\
\text { disagree }\end{array}$} & \multicolumn{3}{|c|}{2 disagree } & 3 und & ecided & & 4 agr & & $5 \mathrm{str}$ & rongly agree \\
\hline df_transport & $\begin{array}{l}\text { Demand flexibility - } \\
\text { means of transportation }\end{array}$ & $\begin{array}{l}1 \text { strong1 } \\
\text { disagree }\end{array}$ & & 2 & isag & & 3 ur & ided & & 4 agr & & $5 \mathrm{str}$ & rongly agree \\
\hline
\end{tabular}

\section{Appendix D}

Detailed data cleaning process

Table A3. Data cleaning process (source: authors' own calculations).

$\begin{array}{cc}\text { Generated Sample } & 2143 \\ \text { Participants with else option } & -50 \\ \text { Cases with contradictory answers } & -7 \\ \text { (co-)owners of more than one installation } & -12 \\ \text { Remaining sample } & 2074\end{array}$

\section{Logistic regression to select demographic variables for PSM-model} Logistic regression summary:

Number of obs $=1954$

LR chi2 $(5)=40.63$

Prob $>$ chi $2=0.0000$

Pseudo R2 $=0.0277$

Log likelihood $=-713.45679$

Table A4. Logistic regression to determine matching variables (source: authors' own calculations).

\begin{tabular}{cccccc}
\hline Participation & Coef. & Std. Err & $z$-Value & $p$-Value & [95\% Conf. Interval] \\
\hline gender & -0.3719166 & 0.1514672 & -2.46 & 0.014 & $-0.6687869-0.0750463$ \\
age & 0.1806668 & 0.0652584 & 2.77 & 0.006 & 0.05276270 .3085708 \\
income & 0.1312171 & 0.0581692 & 2.26 & 0.024 & 0.01720750 .2452267 \\
education & 0.1018039 & 0.0646431 & 1.57 & 0.115 & -0.02489430 .2285022 \\
population & -0.2589355 & 0.0633851 & -4.09 & 0.000 & $-0.383168-0.1347029$ \\
_cons & -1.851322 & 0.0873159 & -21.20 & 0.000 & $-2.022459-1.680186$ \\
\hline
\end{tabular}




\section{References}

1. International Energy Agency. Renewables 2018: Market Analysis and Forecast from 2018 to 2023. 2019. Available online: https:/ / www.iea.org/renewables2018/ power/ (accessed on 3 June 2021).

2. Muruganantham, B.; Gnanadass, R.; Padhy, N.P. Challenges with renewable energy sources and storage in practical distribution systems. Renew. Sustain. Energy Rev. 2017, 73, 125-134. [CrossRef]

3. Da Graça Carvalho, M. EU energy and climate change strategy. Energy 2012, 40, 19-22. [CrossRef]

4. Larsson, S.; Fantazzini, D.; Davidsson, S.; Kullander, S.; Höök, M. Review-ing electricity production cost assessments. Renew. Sustain. Energy Rev. 2014, 30, 170-183. [CrossRef]

5. Aust, B.; Morscher, C. Negative Strompreise in Deutschland. Wirtschaftsdienst 2017, 97, 304-306. [CrossRef]

6. Kubli, M.; Loock, M.; Wüstenhagen, R. The flexible prosumer: Measuring the willingness to co-create distributed flexibility. Energy Policy 2018, 114, 540-548. [CrossRef]

7. Roth, L.; Lowitzsch, J.; Yildiz, Ö.; Hashani, A. Does (Co-)ownership in renewables matter for an electricity consumer's demand flexibility? Empirical evidence from Germany. Energy Res. Soc. Sci. 2018, 46, 169-182. [CrossRef]

8. Belu, R. Fundamentals and Source Characteristics of Renewable energy Systems; CRC Press: Raton, NM, USA, 2019.

9. Strielkowski, W.; Lisin, E.; Astachova, E. Economic sustainability of energy systems and prices in the EU. Entrep. Sustain. Issues 2017, 4, 591-600. [CrossRef]

10. Dudin, M.N.; Frolova, E.E.; Protopopova, O.V.; Mamedov, A.A.; Odintsov, S.V. Study of innovative technologies in the energy industry: Nontraditional and renewable energy sources. Entrep. Sustain. Issues 2019, 6, 1704-1713. [CrossRef]

11. Dunkelberg, H.; Heidrich, T.; Weiß, T.; Hesselbach, J. Energy demand flexibilization of industrial consumers. J. Simul. 2020, 14, 53-63. [CrossRef]

12. Kuzemko, C.; Mitchell, C.; Lockwood, M.; Hoggett, R. Policies, politics and demand side innovations: The untold story of Germany's energy transition. Energy Res. Soc. Sci. 2017, 28, 58-67. [CrossRef]

13. Shariatzadeh, F.; Mandal, P.; Srivastava, A.K. Demand response for sus-tainable energy systems: A review, application and implementation strategy. Renew. Sustain. Energy Rev. 2015, 45, 343-350. [CrossRef]

14. Shen, B.; Ghatikar, G.; Lei, Z.; Li, J.; Wikler, G.; Martin, P. The role of regulatory reforms, market changes, and technology development to make demand response a viable resource in meeting energy challenges. Appl. Energy 2014, 130, 814-823. [CrossRef]

15. Valdes, J.; Poque González, A.B.; Ramirez Camargo, L.; Valin Fenández, M.; Masip Macia, Y.; Dorner, W. Industry, flexibility, and demand response: Applying German energy transition lessons in Chile. Energy Res. Soc. Sci. 2019, 54, 12-25. [CrossRef]

16. Siano, P. Demand response and smart grids-A survey. Renew. Sustain. Energy Rev. 2014, 30, 461-478. [CrossRef]

17. Tristán, A.; Heuberger, F.; Sauer, A. A Methodology to Systematically Identify and Characterize Energy Flexibility Measures in Industrial Systems. Energies 2020, 13, 5887. [CrossRef]

18. Sundt, S.; Rehdanz, K.; Meyerhoff, J. Consumers' Willingness to Accept Time-of-Use Tariffs for Shifting Electricity Demand. Energies 2020, 13, 1895. [CrossRef]

19. Gottwalt, S.; Ketter, W.; Block, C.; Collins, J.; Weinhardt, C. Demand side management-A simulation of household behavior under variable prices. Energy Policy 2011, 39, 8163-8174. [CrossRef]

20. Dütschke, E.; Paetz, A.G. Dynamic electricity pricing-Which programs do consumers prefer? Energy Policy 2013, 59, 226-234. [CrossRef]

21. Stelmach, G.; Zanocco, C.; Flora, J.; Rajagopal, R.; Boudet, H.S. Exploring household energy rules and activities during peak demand to better determine potential responsiveness to time-of-use pricing. Energy Policy 2020, 144, 111608. [CrossRef]

22. Lund, P.D.; Lindgren, J.; Mikkola, J.; Salpakari, J. Review of energy system flexibility measures to enable high levels of variable renewable electricity. Renew. Sustain. Energy Rev. 2015, 45, 785-807. [CrossRef]

23. Abbas, A.O.; Chowdhury, B.H. Using customer-side resources for market-based transmission and distribution level grid servicesA review. Int. J. Electr. Power Energy Syst. 2021, 125, 106480. [CrossRef]

24. Azarova, V.; Cohen, J.J.; Kollmann, A.; Reichl, J. Reducing household electricity consumption during evening peak demand times: Evidence from a field experiment. Energy Policy 2020, 144, 111657. [CrossRef]

25. Podbregar, I.; Filipović, S.; Radovanović, M.; Mirković Isaeva, O.; Šprajc, P. Electricity Prices and Consumer Behavior, Case Study Serbia-Randomized Control Trials Method. Energies 2021, 14, 591. [CrossRef]

26. Nasr, A.K.; Kashan, M.K.; Maleki, A.; Jafari, N.; Hashemi, H. Assessment of Barriers to Renewable Energy Development Using Stakeholders Approach. Entrep. Sustain. Issues 2020, 7, 2526-2541.

27. Yu, Y.; Guo, J. Identifying electricity-saving potential in rural China: Empirical evidence from a household survey. Energy Policy 2016, 94, 1-9. [CrossRef]

28. Whittle, C.; Jones, C.R.; While, A. Empowering householders: Identifying predictors of intentions to use a home energy management system in the United Kingdom. Energy Policy 2020, 139, 111343. [CrossRef]

29. Gołębiowska, B.; Bartczak, A.; Budziński, W. Impact of social comparison on preferences for Demand Side Management in Poland. Energy Policy 2021, 149, 112024. [CrossRef]

30. Frederiks, E.R.; Stenner, K.; Hobman, E.V. Household energy use: Applying behavioural economics to understand consumer decision-making and behaviour. Renew. Sustain. Energy Rev. 2015, 41, 1385-1394. [CrossRef]

31. Genys, D.; Krikštolaitis, R. Clusterization of public perception of nuclear energy in relation to changing political priorities. Insights Reg. Dev. 2020, 2, 750-764. [CrossRef] 
32. Gołębiowska, B.; Bartczak, A.; Czajkowski, M. Energy Demand Management and Social Norms. Energies 2020, 13, 3779. [CrossRef]

33. Rommel, J.; Radtke, J.; Von Jorck, G.; Mey, F.; Yildiz, Ö. Community renewable energy at a crossroads: A think piece on degrowth, technology, and the democratization of the German energy system. J. Clean. Prod. 2018, 197, 1746-1753. [CrossRef]

34. Yildiz, Ö. Financing renewable energy infrastructures via financial citizen participation-The case of Germany. Renew. Energy 2014, 68, 677-685. [CrossRef]

35. Yildiz, Ö.; Sagebiel, J. Consumer (Co-)Ownership and Behaviour: Economic Experiments as a Tool for Analysis. In Energy Transition; Lowitzsch, J., Ed.; Springer International Publishing: Cham, Swizterland, 2019; pp. 99-112.

36. Anda, M.; Temmen, J. Smart metering for residential energy efficiency: The use of community based social marketing for behavioural change and smart grid intro-duction. Renew. Energy 2014, 67, 119-127. [CrossRef]

37. Hoppe, T.; Coenen, F.H.; Bekendam, M.T. Renewable energy cooperatives as a stimulating factor in household energy savings. Energies 2019, 12, 1188. [CrossRef]

38. Goulden, M.; Bedwell, B.; Rennick-Egglestone, S.; Rodden, T.; Spence, A. Smart grids, smart users? The role of the user in demand side management. Energy Res. Soc. Sci. 2014, 2, 21-29. [CrossRef]

39. Ellabban, O.; Abu-Rub, H.; Blaabjerg, F. Renewable energy resources: Cur-rent status, future prospects and their enabling technology. Renew. Sustain. Energy Rev. 2014, 39, 748-764. [CrossRef]

40. Jacobsson, S.; Johnson, A. The diffusion of renewable energy technology: An analytical framework and key issues for research. Energy Policy 2000, 28, 625-640. [CrossRef]

41. Immobilien Scout GmbH Unternehmen. 2020. Available online: http://www.immobilienscout24.de/unternehmen/ immobilienscout24.html (accessed on 14 April 2020).

42. Weiß, J.; Dunkelberg, E.; Gossen, M.; Großmann, D. Bedeutung regional-ökonomischer Faktoren für die Entscheidung von Eigenheimbesitzern. Okol. Wirtsch. Fachz. 2016, 31, 45. [CrossRef]

43. Edwards, P.; Cooper, R.; Roberts, I.; Frost, C. Meta-analysis of randomised trials of monetary incentives and response to mailed questionnaires. J. Epidemiol. Community Health 2005, 59, 987-999. [CrossRef]

44. Young, B.; Bedford, L.; das Nair, R.; Gallant, S.; Littleford, R.; Robertson JF, R.; Schembri, S.; Sullivan, F.M.; Vedhara, K.; Kendrick, D. Unconditional and conditional monetary incentives to in-crease response to mailed questionnaires: A ran-domized controlled study within a trial (SWAT). J. Eval. Clin. Pract. 2020, 26, 893-902. [CrossRef]

45. Nulty, D.D. The adequacy of response rates to online and paper surveys: What can be done? Assess. Eval. High. Educ. 2008, 33, 301-314. [CrossRef]

46. Petchenik, J.; Watermolen, D.J. A Cautionary Note on Using the Internet to Survey Recent Hunter Education Graduates. Hum. Dimens. Wildl. 2011, 16, 216-218. [CrossRef]

47. Sax, L.J.; Gilmartin, S.K.; Bryant, A.N. Assessing response rates and non-response bias in web and paper surveys. Res. High. Educ. 2003, 44, 409-432. [CrossRef]

48. Burns, A.C.; Bush, R.F.; Sinha, N. Marketing Research; Pearson: Boston, MA, USA, 2014.

49. Firth, S.; Lomas, K.; Wright, A.; Wall, R. Identifying trends in the use of domestic appliances from household electricity consumption measurements. Energy Build. 2008, 40, 926-936. [CrossRef]

50. Naus, J.; van Vliet, B.J.; Hendriksen, A. Households as change agents in a Dutch smart energy transition: On power, privacy and participation. Energy Res. Soc. Sci. 2015, 9, 125-136. [CrossRef]

51. Moser, C. The role of perceived control over appliances in the acceptance of electricity load-shifting programmes. Energy Effic. 2017, 10, 1115-1127. [CrossRef]

52. Pallonetto, F.; Oxizidis, S.; Milano, F.; Finn, D. The effect of time-of-use tariffs on the demand response flexibility of an all-electric smart-grid-ready dwelling. Energy Build. 2016, 128, 56-67. [CrossRef]

53. Austin, P.C.; Jembere, N.; Chiu, M. Propensity score matching and complex surveys. Stat. Methods Med. Res. 2018, 27, 1240-1257. [CrossRef]

54. Dugoff, E.H.; Schuler, M.; Stuart, E.A. Generalizing observational study results: Applying propensity score methods to complex surveys. Health Serv. Res. 2014, 49, 284-303. [CrossRef]

55. Frippiat, D.; Marquis, N.; Wiles-Portier, E. Web Surveys in the Social Sciences: An Overview. Population 2010, 65, 285. [CrossRef]

56. Schonlau, M.; Couper, M.P. Options for Conducting Web Surveys. Stat. Sci. 2017, 32, 279-292. [CrossRef]

57. Valliant, R.; Dever, J.A. Estimating Propensity Adjustments for Volunteer Web Surveys. Sociol. Methods Res. 2011, 40, 105-137. [CrossRef]

58. Rosenbaum, P.R.; Rubin, D.B. Constructing a Control Group Using Multivariate Matched Sampling Methods That Incorporate the Propensity Score. Am. Stat. 1985, 39, 33-38.

59. Neukrug, E.; Fawcett, R.C. Essentials of Testing and Assessment: A Practical Guide to Counselors, Social Workers, and Psychologists, 3rd ed.; Cengage Learning: Stanford, CT, USA, 2015.

60. Desgagné, A.; Castilloux, A.-M.; Angers, J.-F.; Le Lorier, J. The Use of the Bootstrap Statistical Method for the Pharmacoeconomic Cost Analysis of Skewed Data. Pharmacoeconomics 1998, 13, 487-497. [CrossRef]

61. Diebold, F.X.; Chen, C. Testing structural stability with endogenous break-point: A size comparison of analytic and bootstrap procedures. J. Econom. 1996, 70, 221-241. [CrossRef]

62. Hall, P.; Horowitz, J.L. Bootstrap Critical Values for Tests Based on Generalized-Method-of-Moments Estimators. Econometrica 1996, 64, 891. [CrossRef] 
63. Klein, S.J.; Coffey, S. Building a sustainable energy future, one community at a time. Renew. Sustain. Energy Rev. 2016, 60, 867-880. [CrossRef]

64. van der Schoor, T.; Scholtens, B. The power of friends and neighbors: A review of community energy research. Curr. Opin. Environ. Sustain. 2019, 39, 71-80. [CrossRef]

65. Von Wirth, T.; Gislason, L.; Seidl, R. Distributed energy systems on a neighbourhood scale: Reviewing drivers of and barriers to social acceptance. Renew. Sustain. Energy Rev. 2018, 82, 2618-2628. [CrossRef]

66. Holstenkamp, L.; Kahla, F. What are community energy companies trying to accomplish? An empirical investigation of investment motives in the German case. Energy Policy 2016, 97, 112-122. [CrossRef]

67. Hanke, F.; Lowitzsch, J. Empowering Vulnerable Consumers to Join Renewable Energy Communities-Towards an Inclusive Design of the Clean Energy Package. Energies 2020, 13, 1615. [CrossRef]

68. Freiman, J.A.; Chalmers, T.C.; Smith, H.; Kuebler, R.R. The Importance of Beta, the Type II Error and Sample Size in the Design and Interpretation of the Ran-domized Control Trial. N. Engl. J. Med. 1978, 299, 690-694. [CrossRef] [PubMed]

69. Zimmerman, D.W. Inflation of Type I Error Rates by Unequal Variances Associated with Parametric, Nonparametric, and Rank-Transformation Tests. Psicológica 2004, 25, 103-133.

70. Hesterberg, T. Bootstrap Methods and Permutation Tests; W.H. Freeman and Company: New York, NY, USA, 2003.

71. Manly, B.F.J. Randomization, Bootstrap and Monte Carlo Methods in Biology, 3rd ed.; Chapman \& Hall/CRC: London, UK, 2007. 